This is the final peer-reviewed accepted manuscript of

Vitale Brovarone A.; Beltrando M.; Malavieille J.; Giuntoli F.; Tondella E.; Groppo C.; Beyssac O.;

Compagnoni R.: Inherited Ocean-Continent Transition zones in deeply subducted terranes: Insights from

Alpine Corsica. LITHOS_ 124. 0024-4937

DOI: 10.1016/j.lithos.2011.02.013

The final published version is available online at:

http://dx.doi.org/10.1016/j.lithos.2011.02.013

Rights / License:

The terms and conditions for the reuse of this version of the manuscript are specified in the publishing policy. For all terms of use and more information see the publisher's website.

This item was downloaded from IRIS Università di Bologna (https://cris.unibo.it/)

When citing, please refer to the published version. 


\title{
Inherited Ocean-Continent Transition zones in deeply subducted terranes: Insights from Alpine Corsica
}

\author{
Alberto Vitale Brovarone ${ }^{\mathrm{a}, \mathrm{b}, *}$, Marco Beltrando $^{\mathrm{a}}$, Jacques Malavieille ${ }^{\mathrm{b}}$, Francesco Giuntoli ${ }^{\mathrm{a}}$, \\ Ermete Tondella ${ }^{\mathrm{a}}$, Chiara Groppo ${ }^{\mathrm{a}}$, Olivier Beyssac ${ }^{\mathrm{c}}$, Roberto Compagnoni ${ }^{\mathrm{a}}$ \\ a Dept. of Mineralogical and Petrological Sciences, University of Torino, via Valperga Caluso 35, I-10125, Torino, Italy \\ b Laboratoire Géosciences Montpellier, UMR 5243, University of Montpellier 2, place E. Bataillon, 34095 Montpellier Cedex 5, France

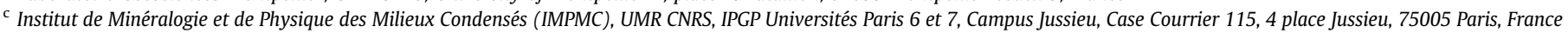

\section{A R T I C L E I N F O}

Article history:

Received 15 March 2010

Accepted 28 February 2011

Available online 5 March 2011

Keywords:

Ocean-Continent Transition

Tethyan rifting

Structural inheritance

Lawsonite eclogite

Alpine Corsica

\begin{abstract}
A B S T R A C T
In the Schistes Lustrés of Alpine Corsica (France) serpentinized mantle rocks are associated with continental basement and meta volcanic/ sedimentary cover rocks. The relationships among these different lithologies are especially well exposed in the Monte San Petrone unit, where Alpine metamorphism reached lawsonite eclogite conditions. The contact between serpentinites and slivers of continental basement, relatively flat lying over several kilometers, is characterized by evidence of cataclastic deformation pre dating Alpine High Pressure ductile fabrics. The serpentinite/continental basement pair is stratigraphically overlain by metasediments with a typical Jurassic Cretaceous supra ophiolitic lithostratigraphy, with metaradiolarites passing upward to marbles and calcschists. Noticeably, no evidence of cataclastic deformation is found in metasediments. These observations indicate that the lithostratigraphy of the Monte San Petrone unit was established during a pre Alpine polyphase evolution, which culminated in extensive brittle deformation along a flat lying detachment fault prior to the deposition of Jurassic sediments. We suggest that the inferred Mesozoic extensional tectonics were related to the opening of the Western Tethys. The Mesozoic architecture of the Monte San Petrone area, which is typical of an Ocean Continent Transition (OCT) zone, was preserved despite Alpine deformation and metamorphism, when the different lithologies (i.e. meta ophiolites, continent derived rocks and metasediments) underwent a common metamorphic evolution, culminating at $T=490550{ }^{\circ} \mathrm{C}$ and $P=2.22 .6 \mathrm{GPa}$. Similar tectono stratigraphic associations are observed in other high pressure terranes of Alpine Corsica, suggesting that inherited OCT type domains may be common in Alpine type orogens.
\end{abstract}

\section{Introduction}

Within the Corsican Sardinian block, which consists of a Hercynian/Variscan basement intruded by large bodies of Permo Carboniferous granitoids, the northeastern part of Corsica, the so called Alpine Corsica (Fig. 1), consists largely of ocean derived sequences emplaced during the Alpine orogeny. In this portion of the Alpine belt and in other subduction related orogens, such as the Western Alps (e.g. Beltrando et al., 2010; Dal Piaz, 1999; Hermann, 1937) and the Apennines (Marroni et al., 1998, 2002), continental basement slivers and meta ophiolites, especially serpentinites, are common. In Alpine Corsica, where the origin of these lithological associations is still debated mainly

\footnotetext{
* Corresponding author. Tel.: +39 011 6705175; fax: +390116705128.

E-mail addresses: alberto.vitale@unito.it (A. Vitale Brovarone), marco.beltrando@unito.it (M. Beltrando), malavie@gm.univ-montp2.fr (J. Malavieille), chiara.groppo@unito.it (C. Groppo), olivier.beyssac@impmc.upmc.fr (O. Beyssac),
}

due to the extent of Alpine deformation, three main interpretations have been proposed to account for such juxtaposition:

i) the continent derived slivers within ophiolites correspond to olistoliths embedded in sedimentary sequences ("sedimentary mélange", e.g. Lahondère, 1996);

ii) the juxtaposition of continent derived rocks and ophiolites results from Alpine compression ("Alpine tectonic mélange": e.g., Durand Delga, 1978, 1984; Faure and Malavieille, 1981; Malavieille, 1983; Mattauer et al., 1981; Péquignot and Potdevin, 1984; Sauvage Rosemberg, 1977);

iii) continental basement slivers and related sedimentary cover represent relics of continental crust thinned during rifting ("continental extensional allochthons"; Lahondère, 1996; Lahondère and Guerrot, 1997).

In the Western Alps, the origin of such lithological associations has also been alternatively ascribed either to Alpine tectonics (Ballèvre and Merle, 1993; Bousquet, 2008; Forster et al., 2004; Gerya et al., 2002; Reddy et al., 2003) or to Mesozoic extensional tectonics related to 


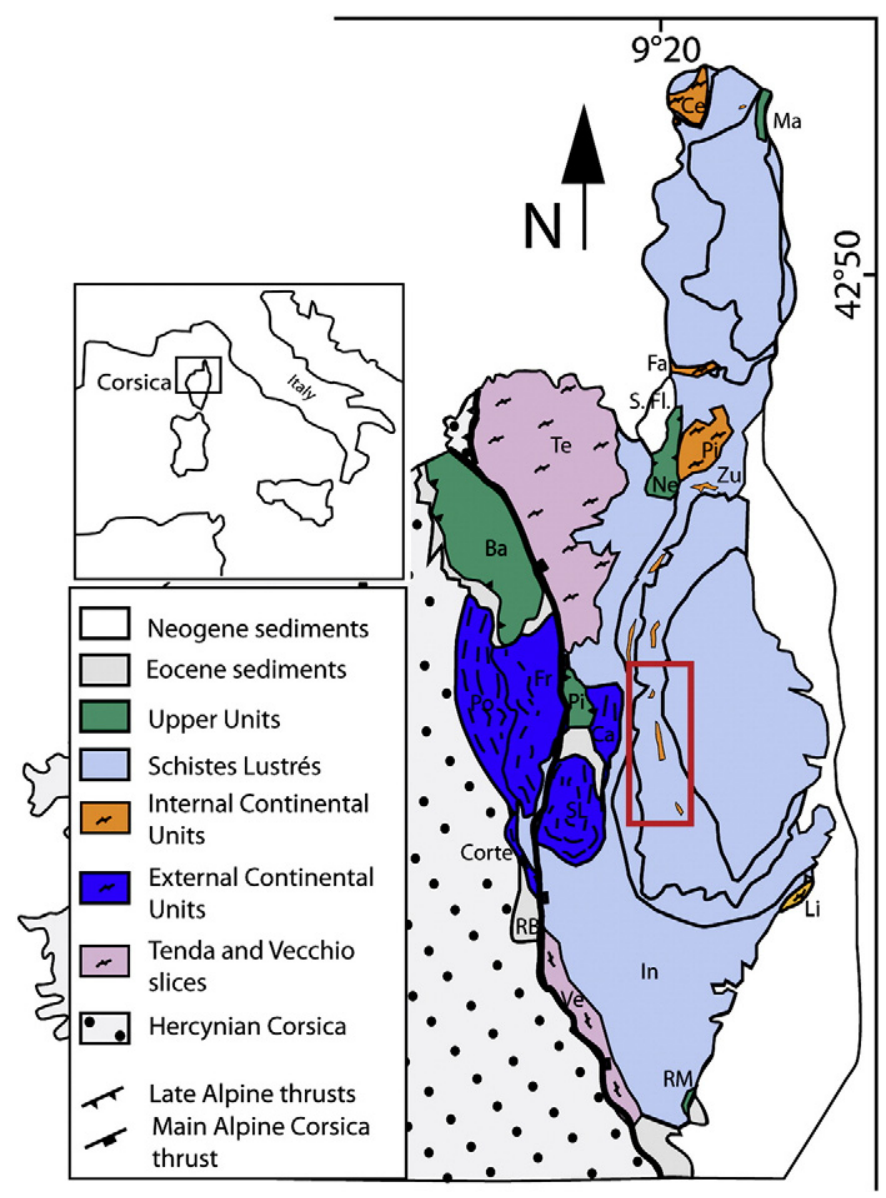

Fig. 1. Simplified map of northern Corsica. The box indicates the Monte San Petrone area. Minor continental slivers are reported in Fig. 13. From Lahondère (1996) and Molli (2008), modified. Ce: Centuri; Fa: Farinole; Ne: Nebbio; Pi: Pigno; S.Fl.: Saint Florent; Ba: Balagne; Po: Popolasca; Fr: Francardo; Ca: Caporalino; SL: Santa Lucia; Ve: Vecchio; Li: Linguizetta; Te: Tenda massif; In: Inzecca region; RM: Rio Magno; Pi: Pineto; Ma: Macinaggio; and Zu: Cima Zuccarello.

opening of the Western Tethys (e.g. Beltrando et al., 2010; Dal Piaz, 1999). The second interpretation is based on a significant number of studies on present day (e.g., Boillot et al., 1980, 1987; Péron Pinvidic and Manatschal, 2009) and fossil Ocean Continent Transition (OCT) zones (e.g., Florineth and Froitzheim, 1994; Froitzheim and Manatschal, 1996; Hermann and Müntener, 1996; Manatschal et al., 2006). The term "OCT" refers to portions of rifted margins where "typical" continental and oceanic lithospheres are separated by extensive regions of exhumed mantle rocks locally overlain by slivers of continental basement, and are known as 'continental extensional allochthons' (e.g., Manatschal, 2004). Drilling along the Iberia/ Newfoundland margins, and reflection and refraction seismic studies suggest that these domains may extend over $>50 \%$ of the present day rifted margins (Péron Pinvidic and Manatschal, 2009).

In these settings, slivers of continental rocks are locally juxtaposed to exhumed mantle rocks as a result of rift related lithospheric thinning (e.g. Florineth and Froitzheim, 1994; Froitzheim and Manatschal, 1996; Hermann and Müntener, 1996; Manatschal et al., 2006; Péron Pinvidic and Manatschal, 2009).

This paper focuses on the High Pressure Low Temperature (HP LT) lawsonite eclogite units of Monte San Petrone in Alpine Corsica, where this particular tectono stratigraphic association is well exposed. The study area will then be compared with similar tectonostratigraphic units found throughout Alpine Corsica, including the blueschist facies Zuccarello unit, and the implications of these findings for the pre Alpine paleogeography will be discussed.

\section{Geological setting}

The island of Corsica is subdivided in two different geological

domains: (1) the Hercynian (or Variscan) Corsica, which originally belonged to the European margin and largely escaped the Alpine orogeny. This domain consists of basement rocks intruded by granitoids, overlain by a sedimentary cover up to the Eocene; and (2) the Alpine Corsica, consisting largely of ophiolitic rocks with their sedimentary cover sequences and subordinate slivers of continental basement that underwent HP/LT metamorphism during the Alpine orogeny. Alpine Corsica can be subdivided into three major sub domains (Fig. 1):

1) the External Continental units to the west, which comprise variably deformed crystalline rock units locally preserving evidence of Variscan deformation and Carboniferous to Permian intrusive rocks. In these units (Tenda, Vecchio, Popolasca/Corte/Razzo Bianco/Santa Lucia/Caporalino slices) continental basement rocks are variably overlain by Permian to Eocene sediments that underwent Alpine metamorphism ranging from low temperature greenschist to blueschist facies conditions (Molli et al., 2006; Tribuzio and Giacomini, 2002).

2) The Schistes Lustrés complex, comprising several tectonometa morphic units that mostly consists of meta ophiolites and their metasedimentary cover rocks, which were derived from the Ligurian portion of the Jurassic Western Tethys. Continental basement slivers of variable size, which are known as Internal Continental Units (e.g. the Farinole, Centuri, and Pigno slices), are commonly found within the Schistes Lustrés units (e.g., Caron and Delcey, 1979; Faure and Malavieille, 1981; Fournier et al., 1991; Jolivet et al., 1990; Lahondère, 1996; Malavieille, 1983; Mattauer et al., 1981: cf. Section 2.1). Metamorphic grade in the Schistes Lustrés increases eastward and ranges from subgreenschist to lawsonite eclogite facies (e.g. Caron and Péquignot, 1986; Péquignot and Potdevin, 1984). In the less metamorphosed Inzecca region of the Schistes Lustrés (Fig. 1), geochemical work on metabasalts indicate a N MORB affinity (Beccaluva et al., 1977; Venturelli et al., 1981), which is considered as a characteristic signature of normal mid ocean basaltic effusions (Desmurs et al., 2002). Otherwise, the paleogeographic provenience of highly deformed terranes of the Schistes Lustrés complex is still under debate. In particular, the origin of the high pressure domain, which consists of meta ophiolites associated with continental basement rocks (cf. Section 1 ), and of the Castagniccia region (Caron and Delcey, 1979; Lahondère, 1996), mostly consist ing of monotonous metasedimentary sequences, are still under debate.

3) The upper Balagne, Nebbio, Rio Magno, Pineto and Macinaggio units, which alternatively consist of ophiolitic rocks, continental basement rocks or Cretaceous metasediments, are characterized by prehnite pumpellyite bearing assemblages in mafic rocks (Bezert and Caby, 1988; Caron, 1994; Dal Piaz and Zirpoli, 1979; Fournier et al., 1991; Malasoma et al., 2006; Péquignot and Potdevin, 1984). Similarly to the Inzecca region of the Schistes Lustrés, metabasalts from the ophiolitic Pineto and Rio Magno units have N MORB geochemical signatures characteristic of internal paleo domains (Padoa et al., 2001; Saccani et al., 2000). In contrast, the Nebbio nappe basalts show enriched E MORB affinity referred to transitional areas (Saccani et al., 2000).

\subsection{Distribution of ophiolites and continent derived rocks}

As mentioned above, most of the tectono metamorphic units of the Schistes Lustrés are characterized by the association of ophiolites and scattered continental slivers (i.e. "Internal Continental Units" of Fig. 1). These continental slivers are found all over the Schistes Lustrés domain, 
with the exception of the metasedimentary Castagniccia unit, and show different tectono metamorphic evolutions with metamorphic peaks locally reaching lawsonite eclogite facies conditions. In the eclogitic Morteda Farinole unit (Lahondère, 1996), continental basement rocks occur between serpentinites and metasediments. Similarly, in the blueschist Campitello unit (Lahondère, 1996) slices of continental basement rocks are found between serpentinites and metasediments. In this case, the continental sliver is alternatively overlain by Triassic dolomite, in the Campitello area, and metaconglomerates, in the Battagliole area (Lahondère, 1996; Rossi et al., 2003). Other slices of continental basement rocks associated with meta ophiolites and metasediments occur in the blueschist Zuccarello and Serra di Pigno areas (Fournier et al., 1991; Lahondère, 1996; Meresse, 2006), and in the Ersa Centuri Unit associated with the Monte Maggiore metaperidotite (Jackson and Ohnenstetter, 1981; Malavieille, 1983; Piccardo and Guarnieri, 2010; Rampone et al., 2009). Slices of continental basement rocks are also found in the Inzecca region, close to the contact with the Hercynian Corsica basement (Sampolo slices: Garfagnoli et al., 2009) or, to the east, in the Aleria plain (Linguizzetta slice: Caron et al., 1990).

Within the Schistes Lustrés nappe, continent derived rocks occur also as variably metamorphosed silicoclastic sediments. In the Balagne nappe continent derived debris is found in several horizons in the sequence, from the Jurassic basalts (Durand Delga et al., 1997) up to the upper Cretaceous sequences (Marroni and Pandolfi, 2003; Sagri et al., 1982). A representative example is found in the Barremian/Aptian Alturaja formation (Marroni et al., 2004). Similar continent derived debris found throughout the high pressure units of Alpine Corsica is known as the Santo Pietro di Tenda metasedimentary formation (e.g., Caron and Delcey, 1979). These rocks are observed both associated with the Tenda Unit and within the Schistes Lustrés nappe. The most notable occurrences of these metasediments within the Schistes Lustrés nappe include the blueschist and eclogite facies metaconglomerates of the Golo valley (Lahondère, 1996), the eclogite facies meta arkose of the Monte San Petrone and Sant'Andrea di Cotone areas (Caron et al., 1981; Péquignot and Potdevin, 1984).

\subsection{Available metamorphic data of the Monte San Petrone unit}

The Monte San Petrone unit, which is the main subject of this study, belongs to the Schistes Lustrés nappe and represents the southern extension of the eclogite facies Morteda Farinole units of Lahondère (1996). It is separated from the underlying Castagniccia unit by a blueschist to greenschist facies shear zone characterized by a thick sliver of metabasalts running north south throughout the Schistes Lustrés complex. This shear zone corresponds to the Mandriale units defined to the north by Lahondère (1996). Previous studies on the Monte San Petrone unit suggested that eclogites formed at 1.0 1.4 GPa and $420{ }^{\circ} \mathrm{C}$ (Caron and Péquignot, 1986), but this estimate has been recently revised to $520 \pm 20^{\circ} \mathrm{C}$ and $2.3 \pm 0.1 \mathrm{GPa}$ (Vitale Brovarone et al., 2011). No geochronological data are available from the Monte San Petrone area, but similar lawsonite eclogites $\left(1.5 \mathrm{GPa} / 500 \pm 50{ }^{\circ} \mathrm{C}\right.$; Lahondère, 1996) from the Farinole unit yielded contrasting ages of $83.8 \pm 4.9 \mathrm{Ma}$ (Sm Nd: Lahondère and Guerrot, 1997) and a phengite ${ }^{40} \mathrm{Ar}{ }^{39} \mathrm{Ar}$ age of about $34 \mathrm{Ma}$ (Brunet et al., 2000).

\section{Tectono-stratigraphy of the Monte San Petrone unit}

The MSP unit is characterized by a basal body of serpentinized basement overlain by a laterally variable lithostratigraphy, which comprises: i) a sliver of continental basement, extending for several kilometers in the NS direction, ii) ophiolite type rocks, and iii) a metasedimentary cover (Figs. 2 and 3 ). The contacts between the basal serpentinite and the overlying lithologies are described in detail in the following sections.

\subsection{Serpentinized basement}

Mantle derived rocks crop out in the eastern part of the MSP unit as a N S elongated body that represents the lowermost structural member of the tectono stratigraphic sequence (Figs. 2 and 3). This composite basement mainly consists of massive or foliated serpentinites, serpenti nized peridotites and small bodies of metagabbros. The top of the serpentinized basement is defined by a tectonic contact, which will be referred to as Basal Tectonic Contact (BTC in Fig. 2 and following). This contact has been interpreted by Péquignot and Potdevin (1984) as an Alpine tectonic contact. In the following sections, ample evidence for its pre Alpine origin will be discussed.

Serpentinites range from highly strained mylonites to rather undeformed ultramafic rocks where the original peridotitic fabrics have been statically serpentinized. Ultramafic mylonites, characterized by a marked mineral stretching lineation defined by relict chromite, are locally found along the contact with the overlying continental rocks (Figs. 4e, f and 5a, b).

Metagabbros crop out mainly to the north, outside the study area, where they overlie the serpentinized basement, below the Basal Tectonic Contact. In the study area metagabbros are otherwise found as small bodies embedded in serpentinite. The outer portion of these bodies is locally characterized by a rodingitic rim, a typical feature of ophiolites. Such rims are generally due to metasomatic processes occurring during seafloor serpentinization (e.g. Coleman, 1977). This feature suggests that the association of metagabbros and serpentinites is primary. The presence of $\mathrm{Cr}$ rich omphacite (smaragdite; Péquignot and Potdevin, 1984) in metagabbros suggests that both metagabbros and the host serpentinite underwent eclogite facies metamorphism.

Serpentinite breccia crops out as lenticular bodies at the top of the serpentinized basement. It is clast supported with local evidence of jigsaw clasts of serpentinite, indicating in situ cataclastic flow (Figs. $4 a, e$, and $5 c$ ).

\subsection{Continental basement}

A sliver of continental basement, ranging in thickness from less than $2 \mathrm{~m}$ to $\sim 20 \mathrm{~m}$, rests directly upon the serpentinized ultramafic basement (Figs. 3 and 4e). Its lower contact coincides with the Basal Tectonic Contact (Figs. 2 and 3), while its upper boundary, whose characteristics will be discussed below, is referred to as the Upper Allochthon Surface (UAS in Fig. 2 and following). Péquignot and Potdevin (1984) interpreted these rocks as meta arkoses of the "Santo Pietro di Tenda" sequence (sensu Caron and Delcey, 1979), whose type locality is on the eastern side of the Tenda massif. These rocks are considered to be Mesozoic sediments derived from the erosion of a continental margin (e.g. Caron and Delcey, 1979; Lahondère, 1996). However, our new field observations reveal that these gneissic rocks are derived from a composite basement crosscut by leucocratic dykes, suggesting that these rocks are a coherent slice of continental crust (Fig. 5d g).

A lithological layering parallel to the Basal Tectonic Contact is observed, with the lower part of the sliver consisting of polycyclic basement with Permian granulite facies garnet bearing micaschists and meta mafic rocks (Martin et al., under review). The garnet bearing micaschists (Fig. 5d, e and f), characterized by relics of centimeter sized pre Alpine HT garnet porphyroclasts (high Mg Fe content, Martin et al., under review) are especially common in the Monte Calleruccio area. In this area, the Alpine paragenesis, consisting of garnet + lawsonite + phengite + chlorite + pumpellyite + quartz, is well developed in the highly strained "Monte Calleruccio mylonite" (cf. Section 4; Fig. 5e). Alpine garnets occur as small crystals or overgrowths on the relict pre Alpine garnets. The two garnets can be distinguished on the basis of their chemistry, the Alpine garnet being characterized by a Ca rich composition (cf. Section 5.1 for more details). Meta mafic rocks usually preserve the original microstructure 

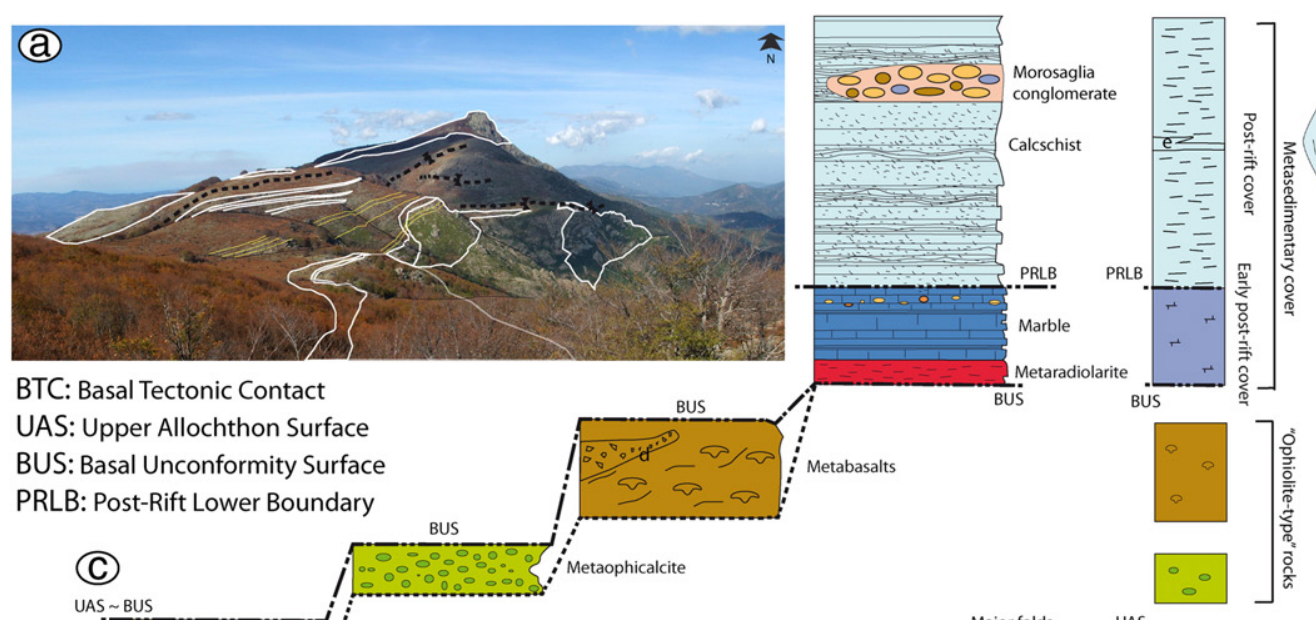

UAS: Upper Allochthon Surface

BUS: Basal Unconformity Surface

PRLB: Post-Rift Lower Boundary
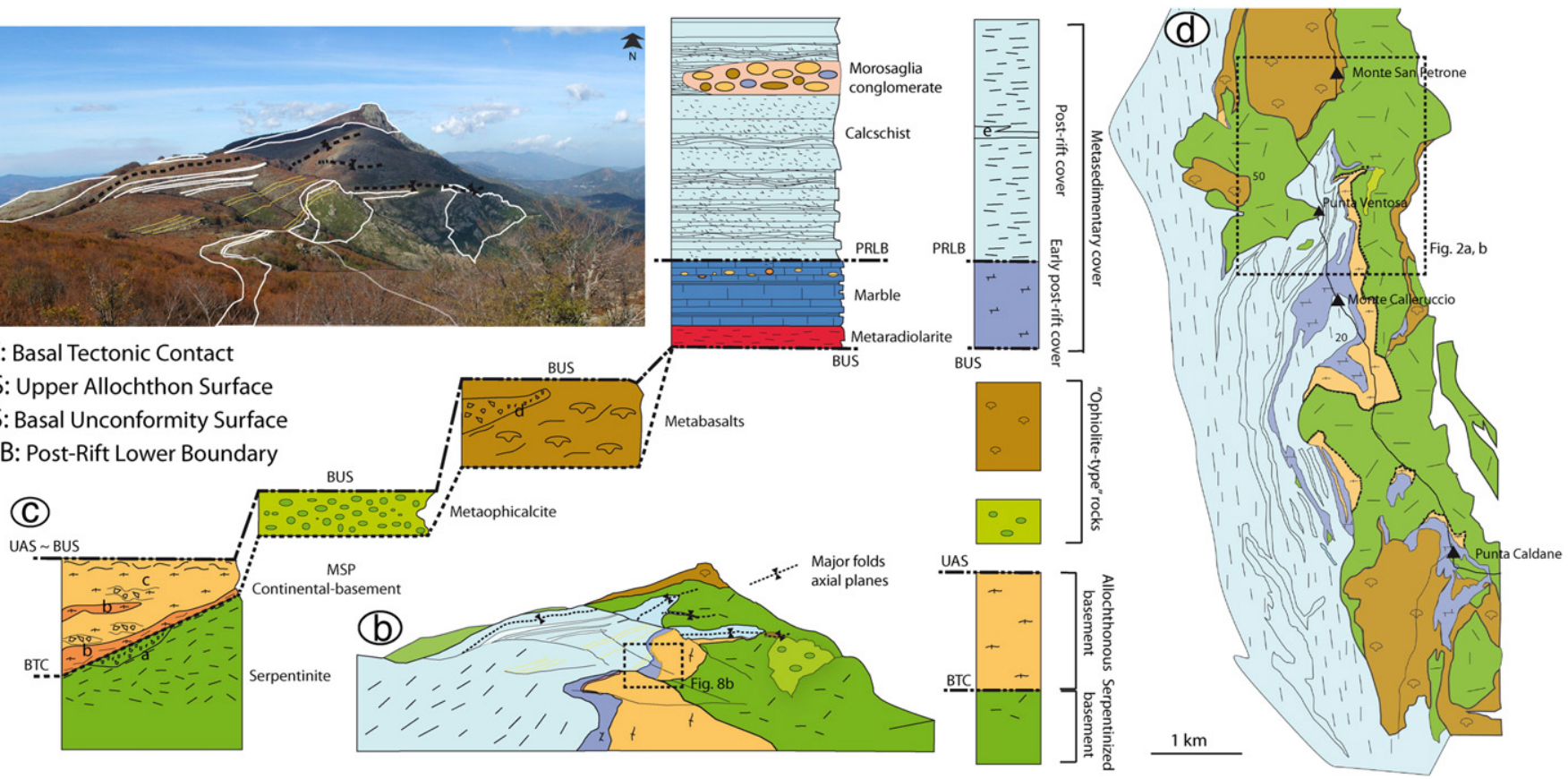

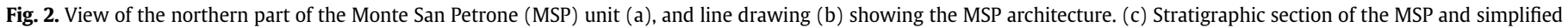

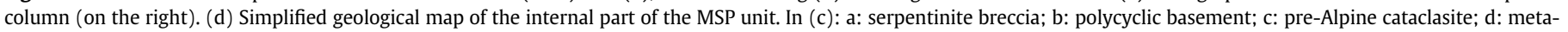
pillow breccia; and e: marble layers.

of the pre Alpine amphibolite, where the original plagioclase and amphibole have been statically replaced by Alpine lawsonite and glaucophane aggregates, respectively.

The most common rocks in the continental sliver are metagranitoids and orthogneisses, whose protoliths range in composition from granite to granodiorite. The gneisses, which are exposed in the upper part of the continental sliver, usually show an augen structure with porphyroclasts of relict igneous $\mathrm{K}$ feldspar wrapped around by the Alpine foliation mainly consisting of white mica and quartz. Metamorphosed dykes, originally ranging in composition from aplites to leucocratic granitoids, are widespread. Primary intrusive contacts between granitoids and the host rocks of the polycyclic basement are locally observed in spite of Alpine transposition (Fig. 5g). In metagranitoids, Alpine HP LT assemblages, mainly represented by Na clinopyroxene, Na amphibole, phengite and lawsonite, are locally well preserved. Alpine garnet is found only occasionally. In the orthogneisses the relics of pre Alpine minerals are mainly igneous $\mathrm{K}$ feldspar and allanite.
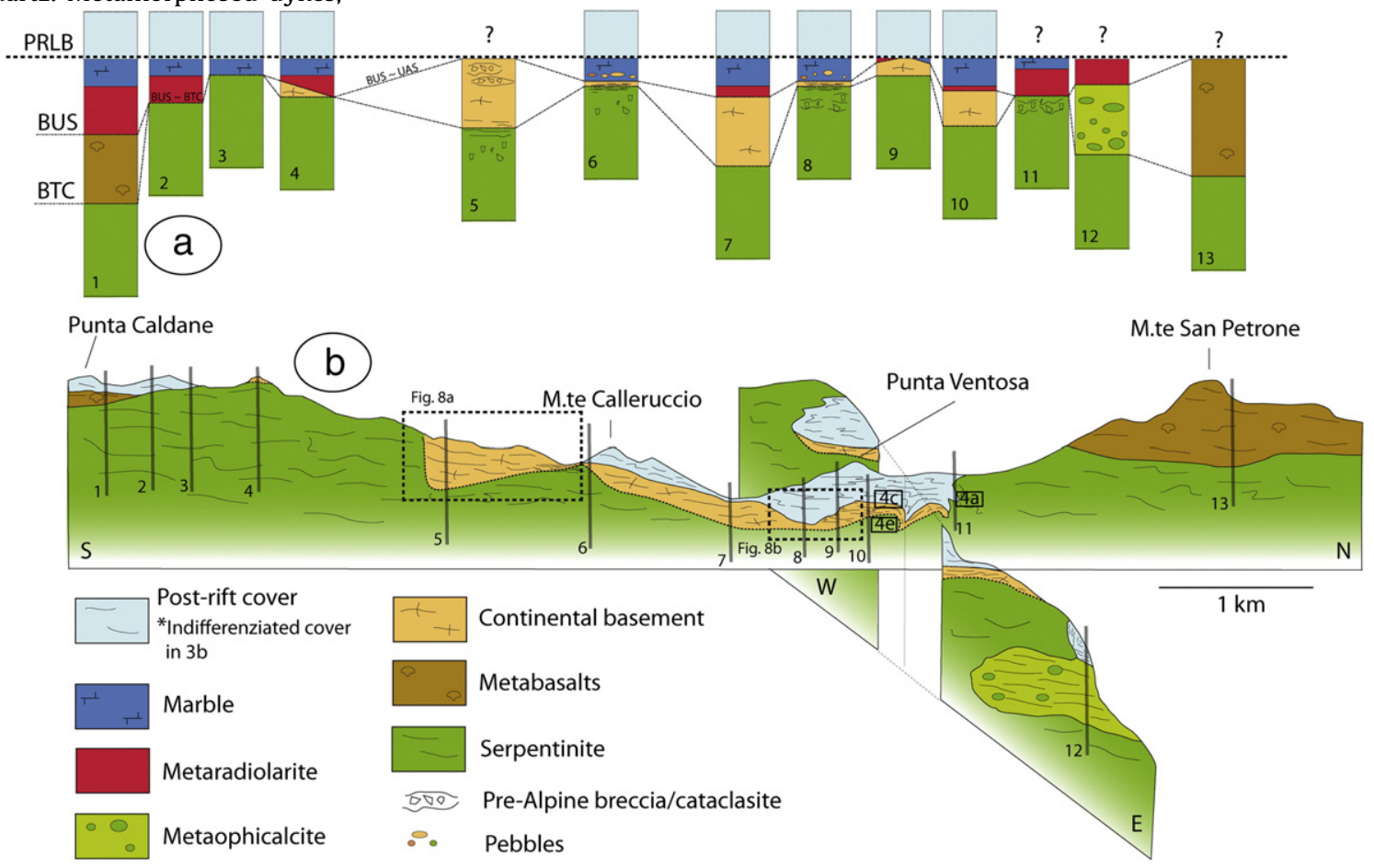

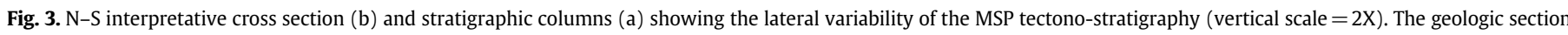
crosses the main MSP summits reported in Fig. 2d. In Fig. 3b, light blue indicates the undifferentiated metasedimentary cover. 

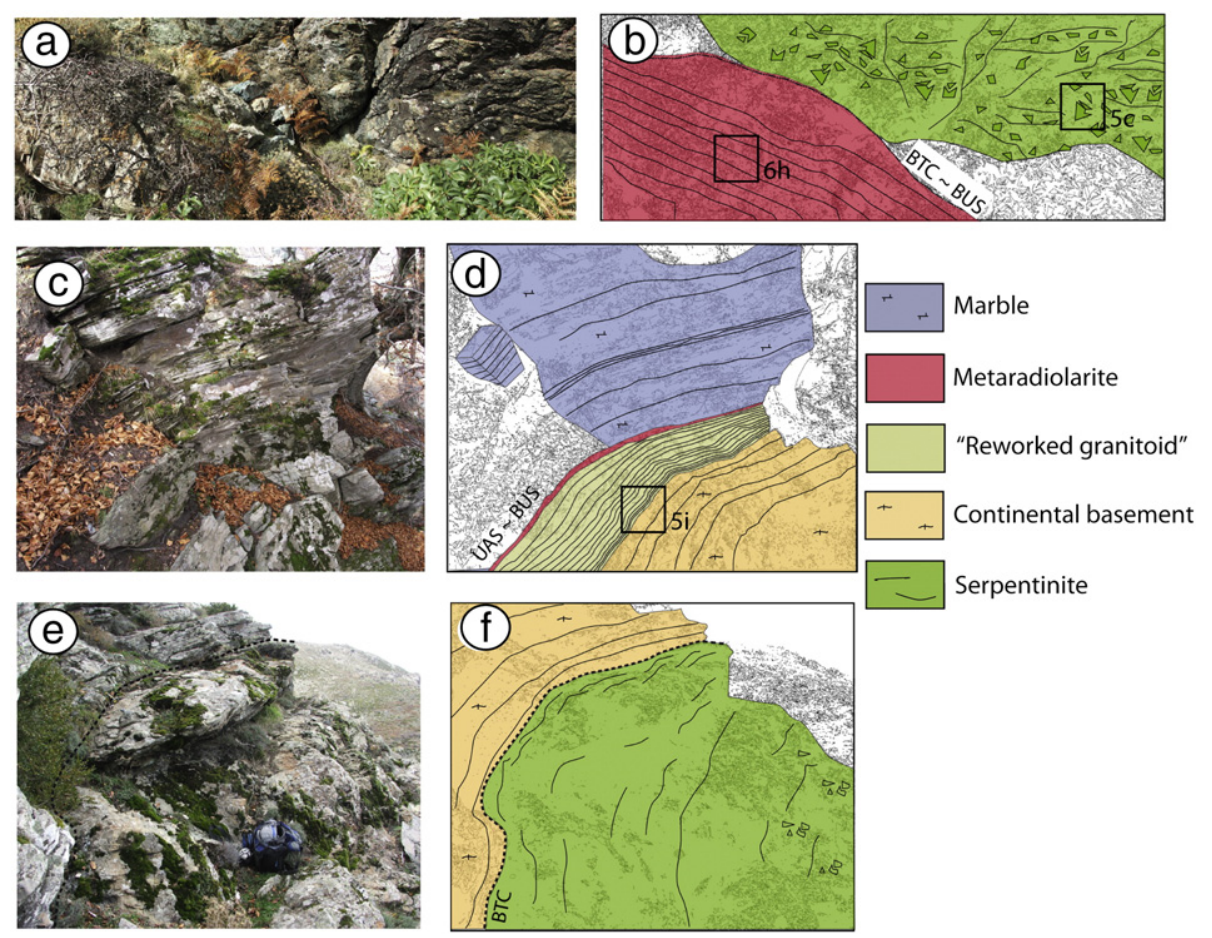

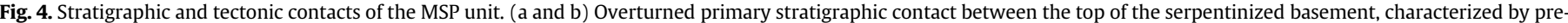

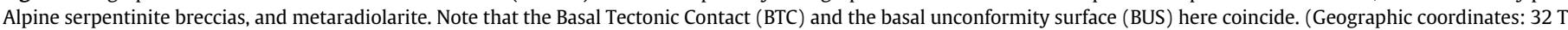

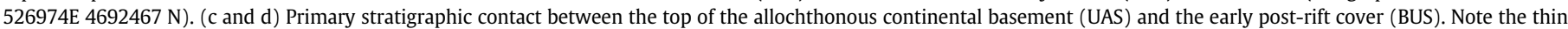

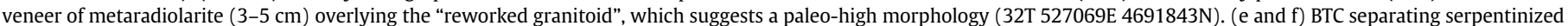
peridotites and a continental basement sliver. The locations of these outcrops are reported in Fig. 3b (32T 527124E 4691700N).

Several somewhat unusual rock types are associated with the continental basement:

(1) A characteristic lithology, consisting of polymineralic clasts comparable to the rocks found in the rest of the continental basement sliver, is locally observed along the lower and upper boundaries of the slice. The best outcrop is located in the area between Bocca di Calleruccio and Bocca di Querciole, where they are found both in outcrop and as loose blocks. They consist of several centimeter wide clasts of continental rocks stretched and wrapped around by the Alpine foliation, which is defined by phengite + blue amphibole \pm lawsonite + quartz. Angular clasts can still be observed in the less deformed domains (Fig. $5 \mathrm{~h}$ ), indicating that these rocks may be derived from an original cataclasite that was formed within the continental sliver prior to the HP Alpine metamorphism and deformation.

(2) A Ca rich metasomatic rim, mainly consisting of lawsonite, is discontinuously found along the lower margin of the continental sliver, which coincides with the Basal Tectonic Contact, just at the contact with the underlying serpentinites.

(3) A thin layer of a highly foliated phengite rich rock, ranging in thickness from a few tens of centimeters to a few meters, is locally observed along the Upper Allochthon Surface, overlying the metagranitoids (Fig. 5i). Its contact with the orthogneisses can be either sharp, such as to the east of Punta Ventosa (Fig. 4c) or transitional, such as at Bocca al Prato.

\section{3. "Ophiolite type" rocks}

This group of rocks consists mainly of: i) meta ultramafic debris, including mostly "detrital ophicalcites" ("OC2 type" of Tricart and Lemoine, 1989), and ii) metabasaltic rocks, such as pillow basalts and pillow breccias, lying above the Basal Tectonic Contact as defined in the previous sections.
"OC2 type meta ophicalcites" are particularly abundant in the northern part of the Monte San Petrone, where they crop out in two main localities (Figs. 2 and 3). They consist of a monogenic metaconglomerate (Fig. 6a and b) with an extremely variable clast/ matrix ratio. Serpentinite clasts are mostly rounded and vary in size from a few millimeters to several meters (Fig. 6a and b). The matrix consists of carbonates, diopside, green amphibole, chlorite, and rare green uvarovitic garnets grown around detrital $\mathrm{Cr}$ spinels. In some localities (e.g. Punta Favalta), reddish clasts of hematite rich fibrous carbonates, which are often observed in OC2 type ophicalcites, are also found (e.g. Framura breccia, Folk and McBride, 1976. Fig. 6c).

Metabasaltic rocks are also found in the same structural position as the continental basement, where the latter wedges out both to the north (Monte San Petrone) and to the south (Punta Caldane; Figs. 2 and 3). They consist both of pillowed and massive lavas and basaltic breccias (Fig. 6d and e). Both types of metabasalts are common in the northern and southern part Monte San Petrone unit, where they form a body with a maximum thickness of about $200 \mathrm{~m}$ (Figs. 2 and 3). Relics of pillows and igneous structures, such as varioles and plagioclase phenocrysts are locally preserved. Such relict domains, ranging in size from a few millimeters to tens of meters, are statically overgrown by Alpine HP LT minerals (Fig. 6f and g) and are wrapped around by the Alpine foliation. Eclogitic assemblages are often well preserved in meta basalts, and consist of omphacite + lawsonite + garnet + phengite + titanite or glaucophane + actinolite + lawsonite + garnet + phengite + titanite (for details, see Vitale Brovarone et al., 2011). Retrogression is generally static and more pervasive in the pillow breccias than in the more competent pillowed basalts.

\subsection{Metasedimentary cover}

A wide range of metasediments is found in the Monte San Petrone Unit. As will be shown below, these metasediments stratigraphically overlie the serpentinized basement, the continental basement and the 

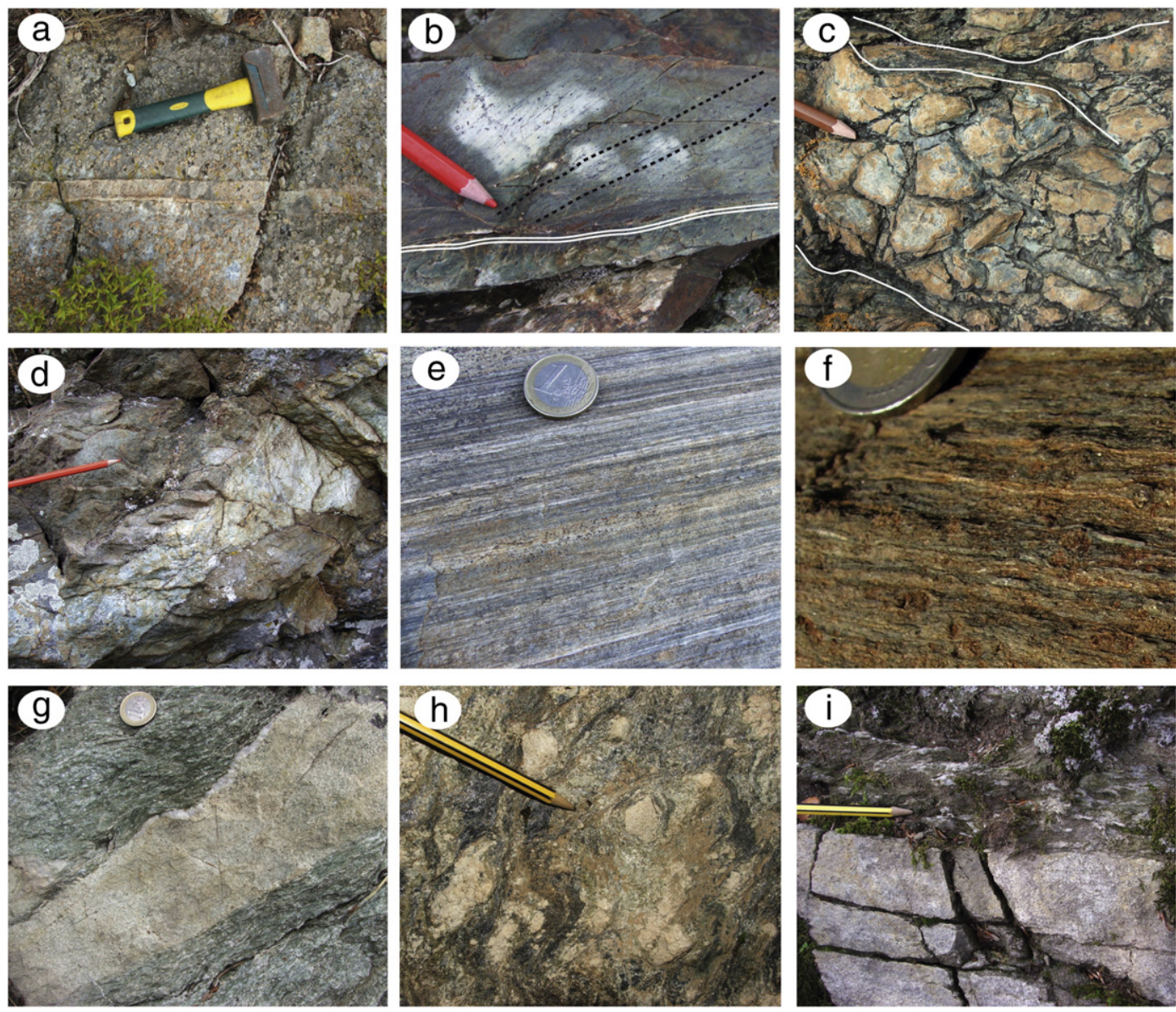

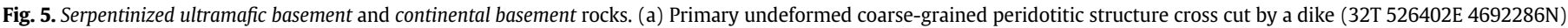

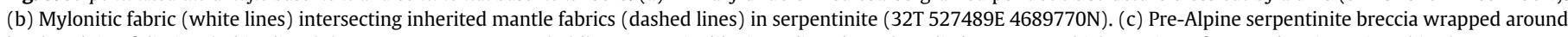

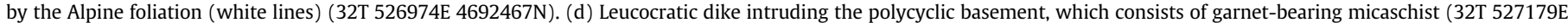

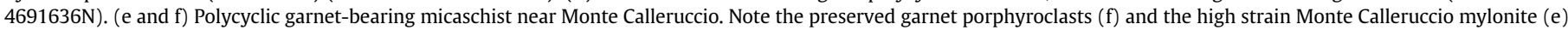

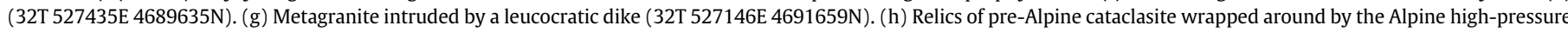

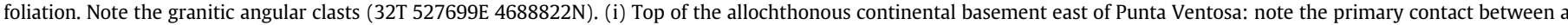

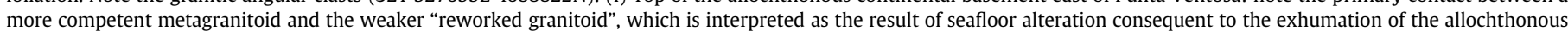
continental sliver (32T 527069E 4691843N).

"ophiolite type" rocks. The lower boundary of the metasedimentary cover, which coincides with both the Basal Tectonic Contact (Fig. 4a) or the Upper Allochthon Surface (Fig. 4c) depending on the absence/ presence of continental basement, respectively, is known as the Basal Unconformity Surface (BUS in Fig. 2 and following).

The cover sediments, which display a marked lateral heterogeneity (Fig. 3), have been subdivided into two main groups, depending on the inferred time of deposition (see below): i) early post rift metasediments, consisting of metaradiolarites and marbles; ii) post rift metasediments, which consist of calcschists sensu lato and metaconglomerates of both continental and ophiolitic origin ("Morosaglia metaconglomerates"; Sedan, 1983). The two groups are separated by a transitional contact characterized by interlayering of both types of lithologies (i.e. marbles and calcschists) for a minimum thickness of several tens of centimeters. No strain gradient is observed across this contact. This contact is hereafter called the Post Rift Lower Boundary (PRLB in Fig. 2 and following), referring to the beginning of the homogeneous post rift cover deposition.

\subsubsection{Early post rift cover}

The early post rift cover mainly consists of a nearly continuous layer of metaradiolarites and marbles, which covers the basement and the meta volcanics. Its thickness varies from several meters (e.g. to the south east of Punta Ventosa and to the east of Aja Rossa, Punta Caldane) to a few tens of centimeters (east of Punta Ventosa) (Figs. 3 and $4 \mathrm{c}$ ).

Metaradiolarites may overlie the different terms of the lithostrati graphy, i.e. serpentinites, serpentinite breccias, ophicalcites, metabasalts and the continental sliver (Fig. 3). The thickest metaradiolarites are systematically found in the vicinity of metabasaltic bodies (see below). The occurrences of metaradiolarites over the different lithologies are best observed: i) to the east of Monte Calleruccio, where amphibole poor whitish metaradiolarites rest on top of meta basalts; ii) in the Bocca al Prato flat, where dark, blue amphibole and tourmaline rich metaradio larites overlie metagranitoids and the polycyclic basement; and iii) to the east of Punta Favalta, where they overlie both serpentinitic metabreccias and ophicalcites. When in contact with the serpentinitic metabreccia (Fig. 4a), they are locally characterized by a Ca rich metasomatic rim ranging in thickness from a few $\mathrm{dm}$ to a few meters. This metasomatic rock, which mainly consists of lawsonite and Na rich pyroxene, is identical to the one found at the bottom of the continental sliver (see Section 3.2). The Alpine fabrics of this rock are cross cut by late pumpellyite veins (Fig. 6h). When in contact with the ophicalcites, metaradiolarites are macroscopically bluish in color because of the presence of blue amphibole, and contain small pinkish garnets; iv) at Punta Caldane, where they variably overlie the allochthonous basement, serpentinites and metabasalts. 

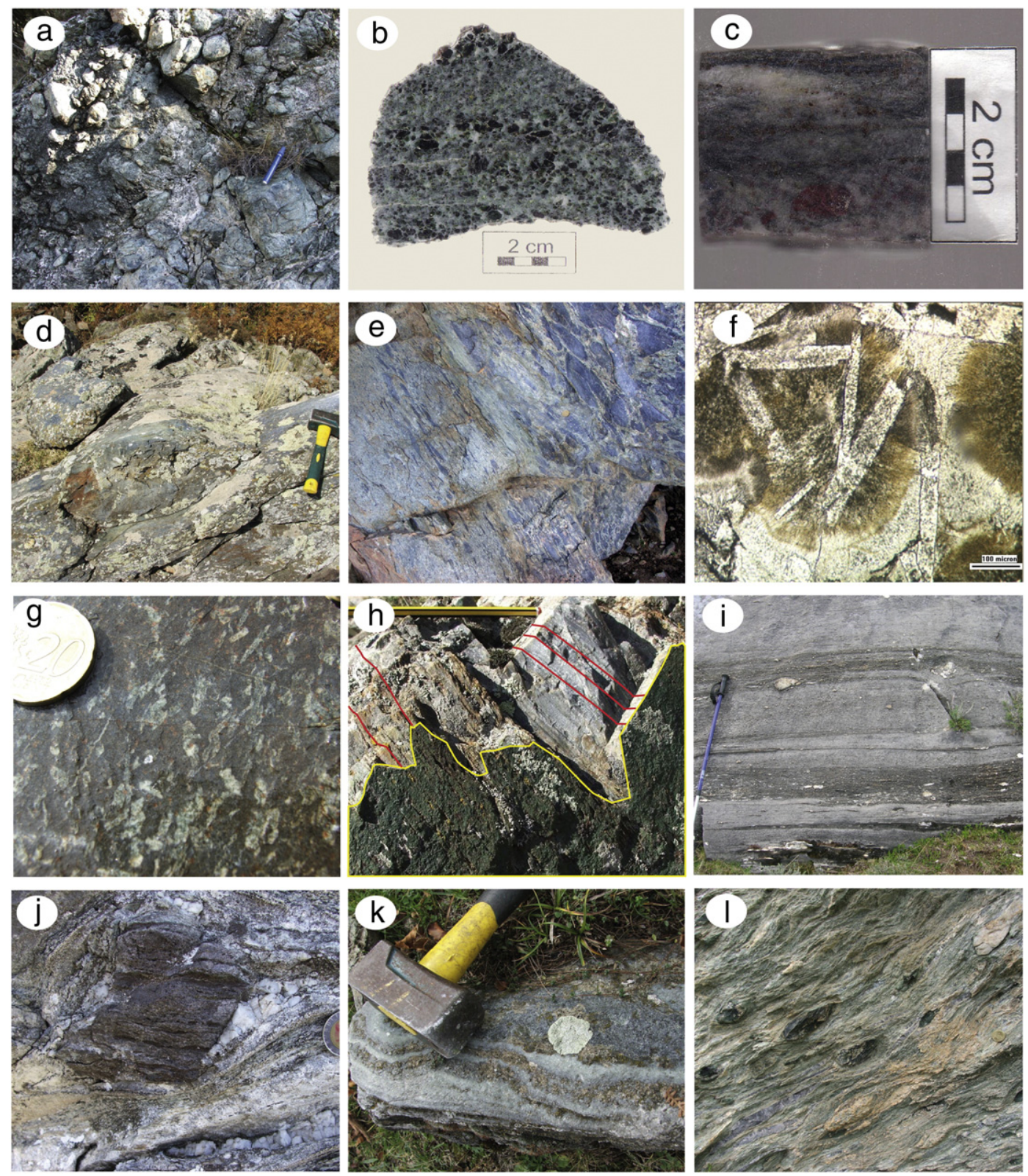

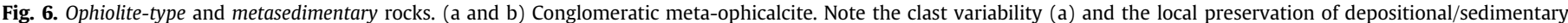

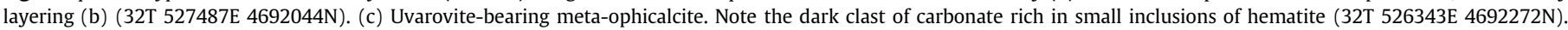

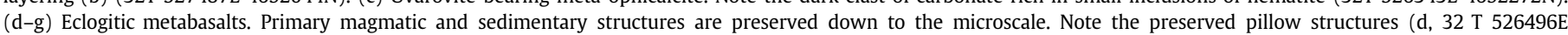

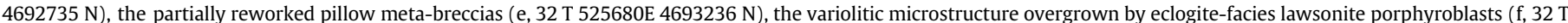

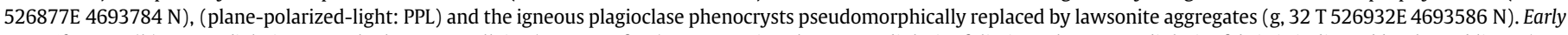

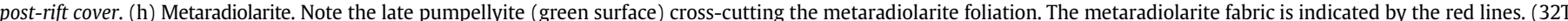

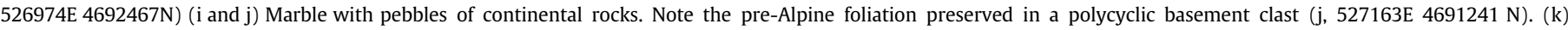

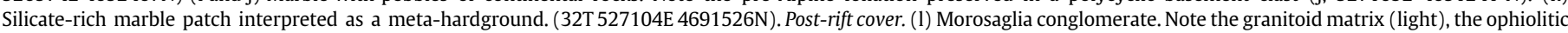
clasts (dark-green), and the stretched carbonate clasts (32T 524847E 4698318N).

Metaradiolarites are overlain by marbles, which are widely distributed all along the Monte San Petrone unit and vary in thickness from a few tens of centimeters to several meters. The thickest portions commonly contain detrital layers with pebbles ranging in diameter from a few centimeters to a few tens of centimeters (e.g., east of Punta Ventosa, Monte Calleruccio and Aja Rossa) (Figs. 3 and 6i). These pebbles, which consist of meta granitoids and polycyclic basement (to the east of Punta Ventosa and Monte Calleruccio, Figs. 3 and $6 \mathrm{j}$ ) or basaltic clasts (in the Aja Rossa area, Fig. 3), are chemically and petrographically comparable to the rocks of the nearby continental sliver. Where the continental sliver displays significant variations in thickness (e.g. east of Punta Ventosa), metaradiolarites and marbles may be associated to form isolated patches less than a meter thick and of limited lateral extent. These thin patches generally contain silicate rich mineral assemblages, including Na pyroxene, Na amphibole, garnet and chlorite (Fig. 6k).

\subsubsection{Post rift cover}

The post rift cover, which is exposed in the western part of the Monte San Petrone unit, consists mainly of calcschists. They are relatively homogeneous, apart from the presence of impure marble layers folded at a hundred meter scale. Calcschists commonly contain lawsonite porphyroblasts pseudomorphically replaced by aggregates of white micas. 
A lenticular layer of metaconglomerates crops out one kilometer to the north of the study area, close to the Morosaglia church, in the uppermost part of the calcschist succession. The metaconglomerate mainly consists of pebbles derived from a granitic basement, but eclogite pebbles and stretched carbonate (now marble) clasts are also observed (Fig. 61).

\section{Alpine deformation}

The Monte San Petrone unit is characterized by polyphase HP deformation, leading to the formation of west dipping fabrics (dip direction N270/30). These fabrics are marked by HP minerals, i.e. omphacite, garnet, lawsonite and glaucophane in metabasalts, phengite, lawsonite and jadeite in metagranitoids, indicating law sonite eclogite facies conditions. Stretching lineations associated with $\mathrm{HP}$ conditions, mostly striking at $\sim \mathrm{N} 250 / 20$, are defined by jadeite and $\mathrm{Na}$ amphibole in metagranitoids and elongated quartz rods in calcschists. Locally, northwest dipping stretching lineations are present in metasediments (Fig. 7a). Highly strained domains, such as in the Monte Calleruccio area, generally preserve evidence of coaxial deformation, as indicated by symmetric strain fringes around garnet porphyroclasts. These microstructural observations are at odds with the widespread occurrence of sheath folds both at the meso and macro scale. Indeed, in the metagranitoids, HP mineral fabrics (phengite: $\mathrm{Si} \sim 3.6$ a.p.f.u.) and asymmetric strain fringes around garnet porphyroclasts locally indicate top to the east sense of shear.
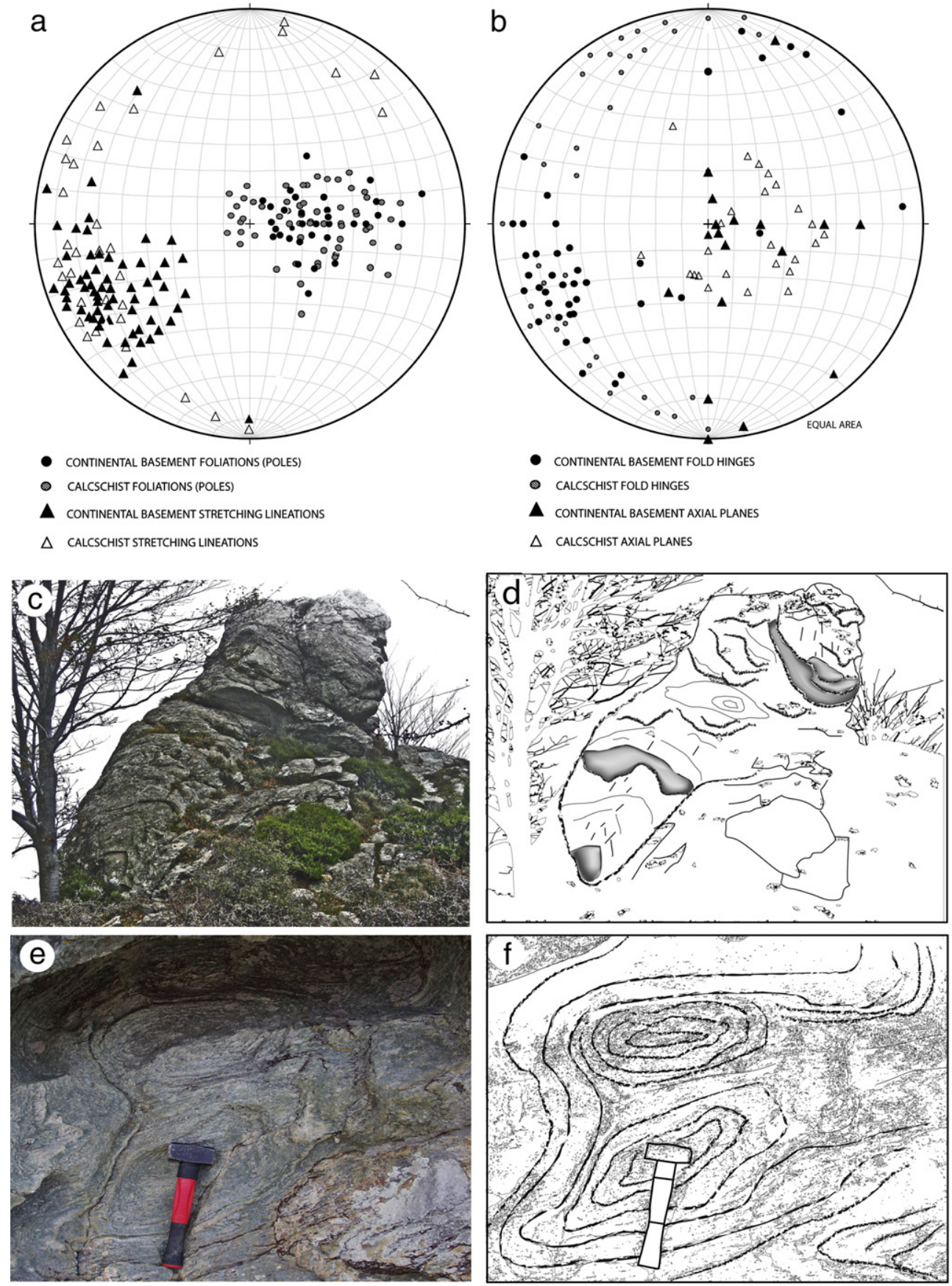

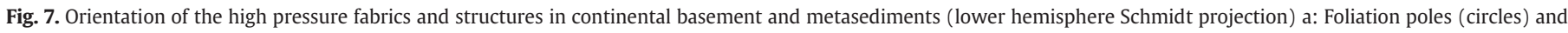

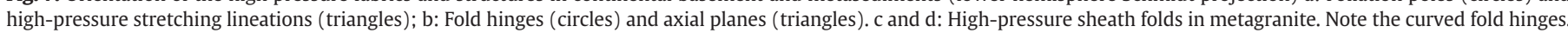
e and f: detail of high-pressure sheath folds in metagranite (32T 5272069E 4691548N). 
Despite that, microstructural evidence for non coaxial deformation is relatively rare, suggesting either that the observed deformation pattern resulted from complex strain partitioning within an overall coaxial flow or, alternatively, that the different HP fabrics found in the Monte San Petrone formed at different times.

Non cylindrical folds are typically found both within the thickest parts of continental basement, giving rise to meter scale sheath folds, and in the northern part of the Monte San Petrone, where the entire lithostratigraphy is affected by synformal and antiformal structures with NE SW trending fold axes.

On the other hand, hundred meter scale isoclinal folds are commonly observed in the post rift cover (Fig. 2d). All folds are characterized by highly scattered fold hinges, with a maximum coinciding with the mineral stretching lineations, while the orientation of the axial planes is significantly more uniform (poles $=\sim 90 / 70$ ). These features are typical of folds progressively rotating into parallelism with the maximum stretching direction (Fig. 7b) (e.g., Alsop and Holdsworth, 2004).

Importantly, a local angular discordance is observed between the HP fabrics and the regional scale, internal lithological boundaries (i.e. BTC, UAS, BUS and PRLB of Figs. 2, 3, 4 and 8), suggesting that such contacts were formed prior to HP deformation. This is especially evident in the Monte Calleruccio area, where the rather flat Alpine fabrics cut across the Basal Tectonic Contact forming the "Monte Calleruccio mylonite" in both serpentinites and continental basement rocks (Fig. 8a). Similar relationships are observed to the east of Punta Ventosa, where the allochthonous basement, which is separated from the metasediments by the Basal Unconformity Surface, tapers southward (Fig. 8b). Significantly, the Alpine metamorphic fabrics are discordant with respect to the Basal Unconformity Surface.

Retrograde fabrics are rarely found in the study area. They formed under epidote blueschist conditions and are parallel to the eclogitic fabrics. These fabrics are especially pervasive along the shear zone separating the Monte San Petrone unit from the underlying Castagniccia unit, where shear bands indicate a top to the East sense of shear. Further away from this contact, blueschist facies deformation locally leads to minor reworking of the eclogitic fabrics/ mineral assemblages. Greenschist retrogression is generally static, except for the metasedi ments, where it is locally associated with mineral fabrics. In continental rocks and metabasalts greenschist facies retrogression is shown by the pseudomorphic growth of albite and chlorite porphyroblasts after blue amphibole or Na pyroxene and garnet, respectively.

\section{Petrology}

In many orogens, the association/juxtaposition of lithologies of different origin (e.g. continental rocks, mantle derived rocks, meta ophiolites and metasediments) has been interpreted as diagnostic of tectonic mélanges formed in a "subduction channel" (e.g., Agard et al., 2009; Cloos and Shreve, 1988; Federico et al., 2007; Garcia Casco et al., 2002; Shreve and Cloos, 1986). Numerical models show that this mechanism implies that the different lithologies underwent indepen dent $P T$ paths (e.g., Gerya et al., 2002), as also proposed in natural settings (e.g., Brouwer et al., 2005; Federico et al., 2007; Garcia Casco et al., 2002). In order to test this possibility for the Monte San Petrone lithologies, we will compare $P T$ estimates obtained with different
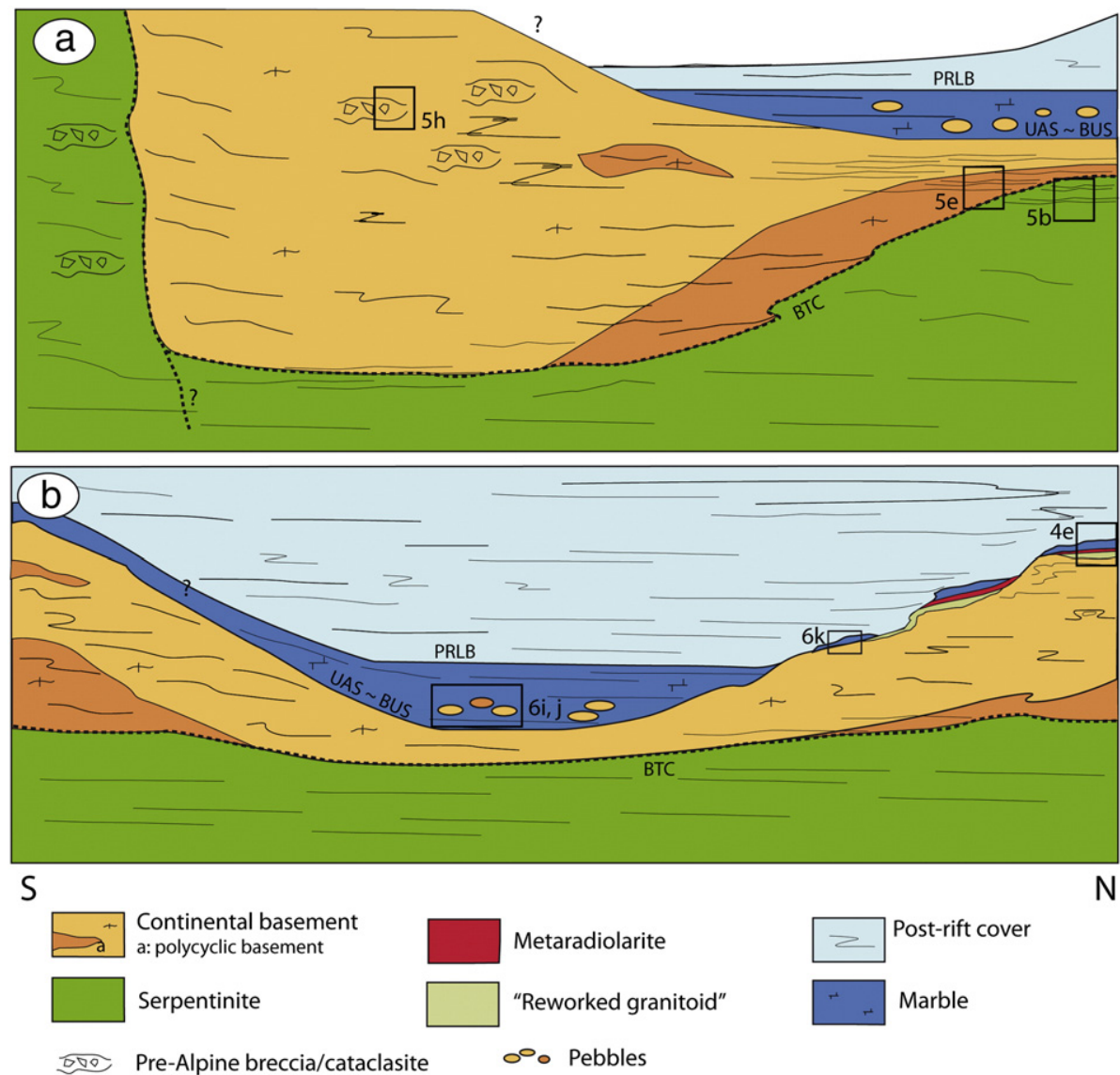

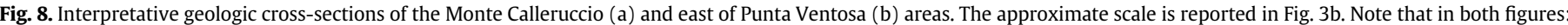

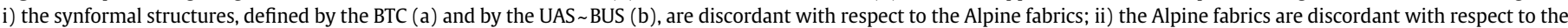

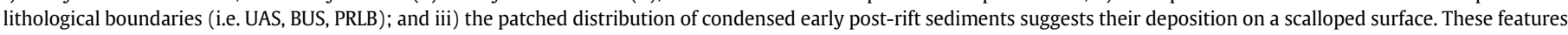
indicate an inheritance from pre-Alpine structures. Question marks in (a) indicate eroded or non-exposed areas. 
techniques from different lithologies, namely continental rocks and cover metasediments. These results will be then compared with those recently obtained from metabasalts of the same area (Vitale Brovarone et al., 2011), for the purpose of testing whether the different rock types underwent analogous or different $P T$ conditions. A detailed discussion of the $P T$ evolution of the studied rocks is reported in Section 7.3.2.

\subsection{Continental rocks}

In order to make a direct comparison with previous results obtained from metabasalts (Vitale Brovarone et al., 2011), a continental rock of mafic composition has been selected for $P T$ estimates. This rock has been selected because its bulk chemical composition and mineralogy are comparable with those of ophiolitic metabasalts, thus allowing the use of the same thermodynamic database used by Vitale Brovarone et al. (2011). In addition, this rock is the continental lithotype most suitable for pseudosection calcula tion. In fact, it shows only structural and not mineralogical relics of pre Alpine assemblages, and preserves well the Alpine HP mineral assemblage, usually retrogressed in the metagranitoids. The selected sample (OF3584) belongs to the polycyclic basement, which pre serves relics of a pre Alpine amphibolite facies microstructure defined by amphibole and plagioclase sites (Fig. 9a) pseudomorphi cally replaced by Alpine minerals (Table 1 ). The pre Alpine HT amphiboles, which are outlined by fine grained alignments of titanite, are fully and mimetically overgrown by Alpine Na amphibole, whereas the plagioclases are replaced by lawsonite and phengite aggregates. Na amphibole, phengite and lawsonite are also present as fine grained crystals defining an Alpine fabric. Fine grained Alpine garnet is rare and locally corroded at its rim (Fig. 10b). No evidence of pre Alpine garnet has been observed in this sample.

Garnet, amphibole, lawsonite and phengite were analyzed with a Cambridge Stereoscan 360 SEM equipment with an EDS Energy 200 and a Pentafet detector (Oxford Instruments) at the Department of Mineralogical and Petrological Sciences, University of Torino (Italy). The operating conditions were: $50 \mathrm{~s}$ counting time and $15 \mathrm{kV}$ accelerating voltage. SEM EDS quantitative data (spot size $=2 \mu \mathrm{m}$ ) were acquired and managed using the Microanalysis Suite Issue 12, INCA Suite version 4.01; the raw data were calibrated on natural mineral standards and the $\rho \Phi Z$ correction (Pouchou and Pichoir,

Table 1

Bulk-rock compositions and representative analyses of blue-amphiboles, garnets and phengites of sample OF3584.

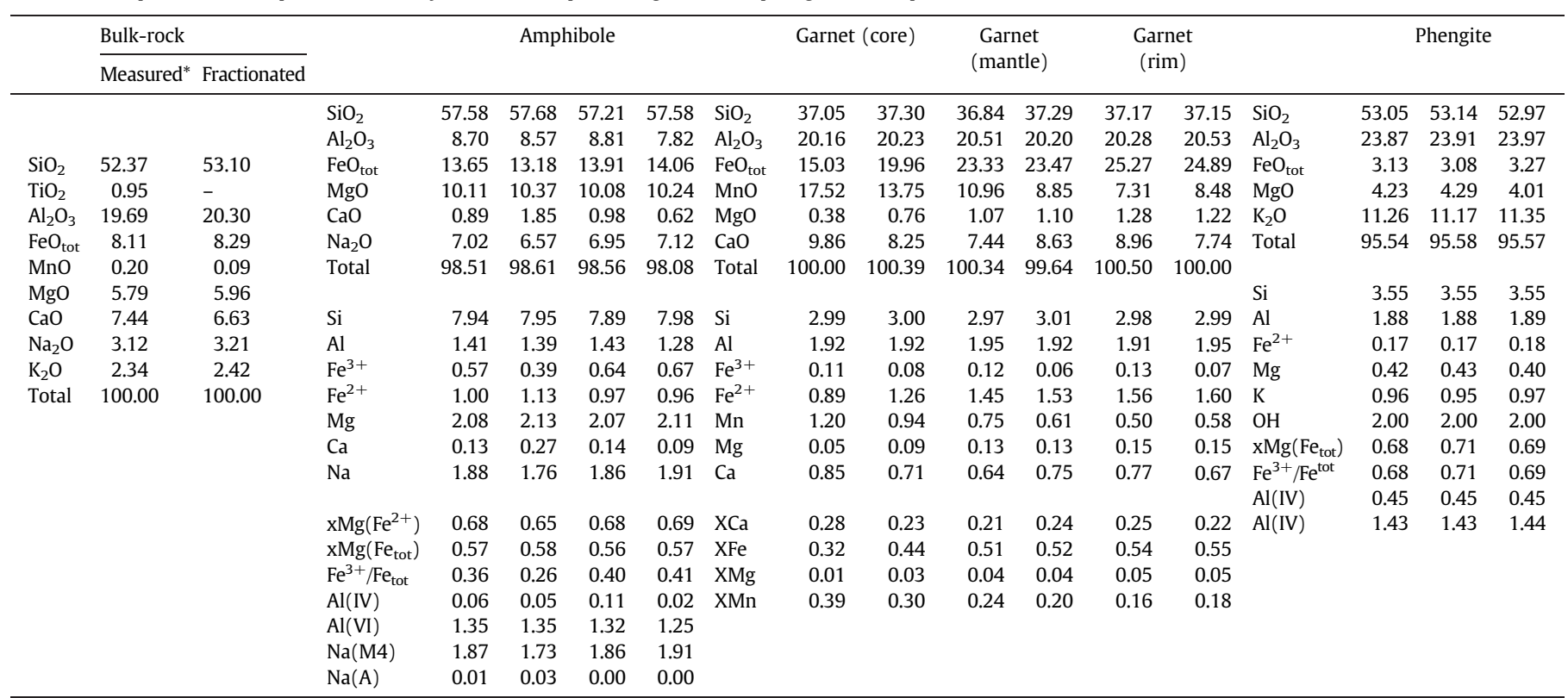

*Bulk-rock chemistry acquired by SEM-EDS as average of 12 areal analyses. In amphiboles TiO2, MnO and K2O are below the detection limit. 
1988) was applied. Representative SEM EDS analyses of garnet, amphibole and phengite are reported in Table 1.

The $\mathrm{Na}$ amphibole plots in the glaucophane field (Leake et al., 1997) (Fig. 9b) and is generally poorly zoned with $X_{\mathrm{Mg}}=0.560 .58$, $\mathrm{Na}_{(\mathrm{M} 4)}=1.731 .91$, and $\mathrm{Al}^{\mathrm{IV}}=0.020 .011$ (Table 1 ).

Garnet shows a gradual growth zoning (Fig. 10) with $X_{M n}$ decreasing $\left(\mathrm{X}_{\mathrm{Mn}}=0.390 .16\right)$, and $\mathrm{X}_{\mathrm{Fe}}$ and $\mathrm{X}_{\mathrm{Mg}}$ increasing $\left(\mathrm{X}_{\mathrm{Fe}}=0.320 .55\right.$ and $\left.\mathrm{X}_{\mathrm{Mg}}=0.010 .05\right)$, from core to rim, respectively (Table 1). The grossular content $\left(\mathrm{X}_{\mathrm{Ca}}\right)$ appears to be more constant and comprised between 0.21 and 0.28 .

Phengite does not show significant chemical zoning, and is characterized by a high celadonitic substitution ( $\mathrm{Si}$ 3.6 a.p.f.u, Table

\subsubsection{Pseudosection modeling}

The bulk rock chemical composition of the sample used for the pseudosection modeling (continental metamafic sample OF3584) was acquired as average of 12 SEM EDS analyses on $4.70 \times 3.20 \mathrm{~mm}$ areas. Sample OF3584 has been modeled in the system MnNKCFMASH. $\mathrm{Fe}_{2} \mathrm{O}_{3}$ was not included in the system because the solid solution models for $\mathrm{Fe}^{+3}$ silicates are not very accurate and only amphibole contains some $\mathrm{Fe}^{+3}$. Considering all $\mathrm{Fe}$ as $\mathrm{Fe}^{2+}$, higher $T$ estimates will result from the $\mathrm{Fe} \mathrm{Mg}$ exchange between garnet and clinopyroxene geothermometer (Ghent et al., 2009). Corrections for Ca, Si and Al in
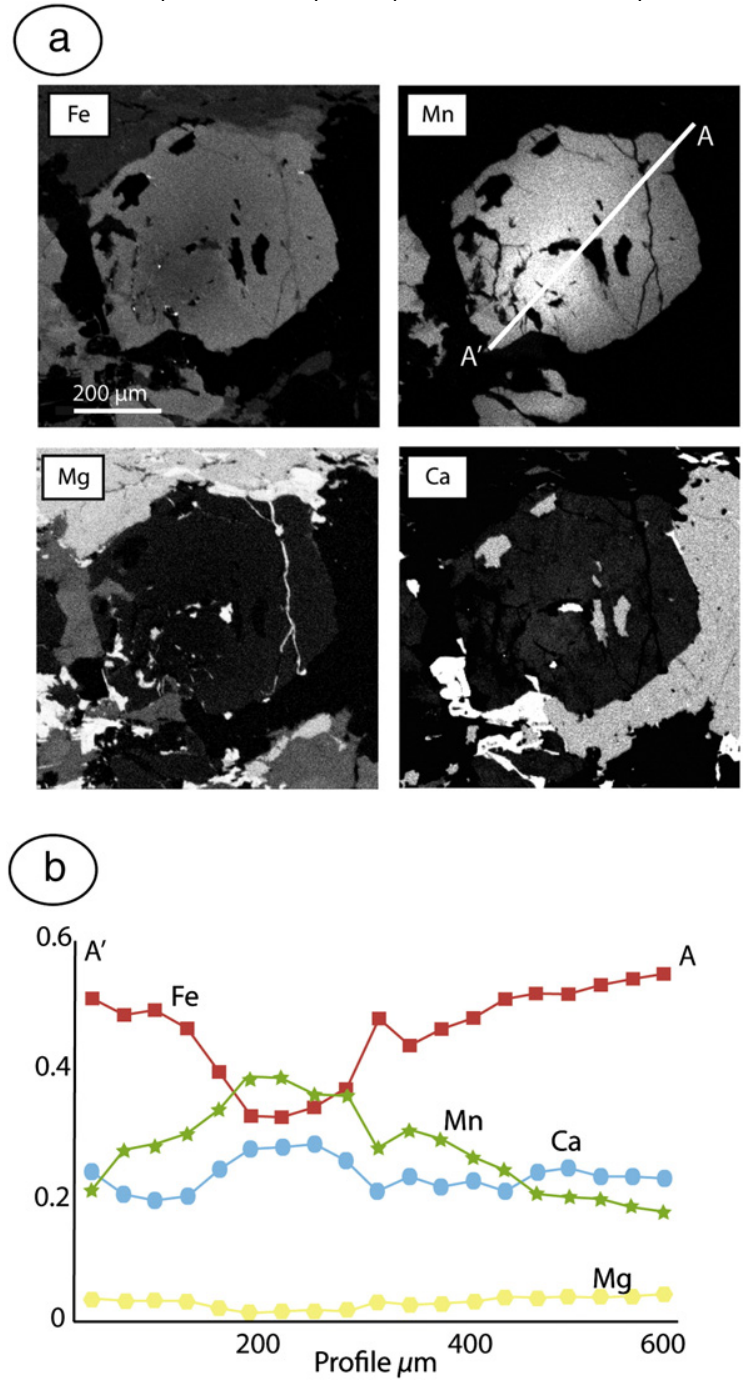

Fig. 10. (a) Compositional Fe, Mn, Mg and Ca X-ray maps of OF3584 garnet. Note that the partially corroded/fragmented garnet is compositionally zoned with $\mathrm{Mn}$ and $\mathrm{Ca}$ decreasing and Fe and $\mathrm{Mg}$ increasing from core to rim, respectively. (b) Compositional $\mathrm{Mg}, \mathrm{Ca}, \mathrm{Fe}$ and $\mathrm{Mn}$ profile of garnet in sample OF3584. titanite and $\mathrm{Ca}$ in apatite were applied. The effects of possible chemical fractionation due to the growth of garnet porphyroblasts have been considered. More in detail, bulk compositions effectively reacting during each stage of garnet growth were calculated following the method described by Evans (2004) and Gaidies et al. (2006). This method applies a Rayleigh fractionation model based on measured Mn content of garnet and requires that a strong linear correlation between the concentration of Mn versus $\mathrm{Fe}, \mathrm{Mg}$ and $\mathrm{Ca}$ in garnet exists (for details, see Vitale Brovarone et al., 2011).

Pseudosections were calculated using Perple_X (Connolly, 1990, 2005; 07 version) and the internally consistent thermodynamic database of Holland and Powell (1998, revised 2004). The phases considered in the calculation were: garnet, omphacite, lawsonite, zoisite/clinozoisite, amphibole, phengite, paragonite, quartz/coesite, plagioclase and chlorite. The following solid solution models were used: garnet and phengite (Holland and Powell, 1998), omphacite (Holland and Powell, 1996), plagioclase (Newton et al., 1980), and chlorite (Holland and Powell, 1998). Amphibole was modeled using the glaucophane tremolite tschermakite pargasite (GITrTsPg) solid solution model (Wei and Powell, 2003; White et al., 2003), which takes into account the miscibility gap between $\mathrm{Ca}$ and $\mathrm{Na}$ amphiboles. $\mathrm{H}_{2} \mathrm{O}$ was assumed to be present in excess: this assumption is supported by the abundance of the hydrous phases lawsonite, phengite and amphibole. In addition, water saturation is essential to consider the lawsonite stability (Clarke et al., 2006). An $a_{(\mathrm{H} 2 \mathrm{O})}=1$ has been used because the presence of titanite instead of rutile implies a very low $\mathrm{CO}_{2}$ activity (e.g., Castelli et al., 2007).

The modeled Si content in phengite is generally overestimated with respect to that measured in the selected sample. This may be due to the fact that phengite did not completely equilibrate at peak conditions (e.g., Ferraris et al., 2005).

Peak conditions of $460<T<490{ }^{\circ} \mathrm{C}$ and $2.3<P<2.6 \mathrm{GPa}$ have been estimated using the garnet compositional isopleths $\left(\mathrm{X}_{\mathrm{Grs}}\right.$ and $\left.\mathrm{X}_{\mathrm{Prp}}\right)$. These modeled $P T$ conditions fall in the tri variant field garnet + lawsonite + phengite + glaucophane + actinolite + chlorite + omphacite (field 1 in Fig. 11) that slightly differs from the observed assemblage, in which actinolite, omphacite and chlorite are lacking. On the contrary, the observed assemblage is represented by the quadri variant field garnet + lawsonite + phengite + glaucophane + omphacite + quartz (field 4 in Fig. 11 with very low amount of omphacite), modeled at $T>520^{\circ} \mathrm{C}$. Therefore, the $T$ estimates inferred from garnet compositions have been considered as minimum temperatures, on the basis of the following observations: 1) garnet is partially corroded at the rim: therefore, $T$ modeled using rim compositions might not be representative of peak conditions; 2 ) the modeled amount of omphacite + actinolite + chlorite in the tri and quadri variant fields 1 to 4 of Fig. 11 is very low ( $<10$ vol.\%) and does not invalidate the results of the pseudosection; and 3) the lack of omphacite in the observed assemblage might be due the presence of inherited microchemical domains storing $\mathrm{Ca}$, such as the pre Alpine plagioclase and amphibole sites (Fig. 9a), which could buffer the omphacite formation in the natural sample.

\subsection{Metasediments}

In the Mont San Petrone calcschists, peak assemblages are commonly statically overprinted during blueschist/greenschist facies retrogression. HP metamorphism is documented by relics of lawsonite porphyroclasts and small pale blue chloritoid fragment generally overgrown by paragonite and chlorite, respectively. Thus, the estimate of peak metamorphic conditions of metasediments by means of traditional thermobarometry or phase diagram modeling is often complicated by the pervasive retrogression.

Since the studied metasedimentary cover is rich in Carbonaceous Material (CM), peak $T$ conditions may be better estimated by Raman Spectroscopy of CM (RSCM thermometry). RSCM thermometry is based on the quantitative study of the degree of graphitization of CM, 


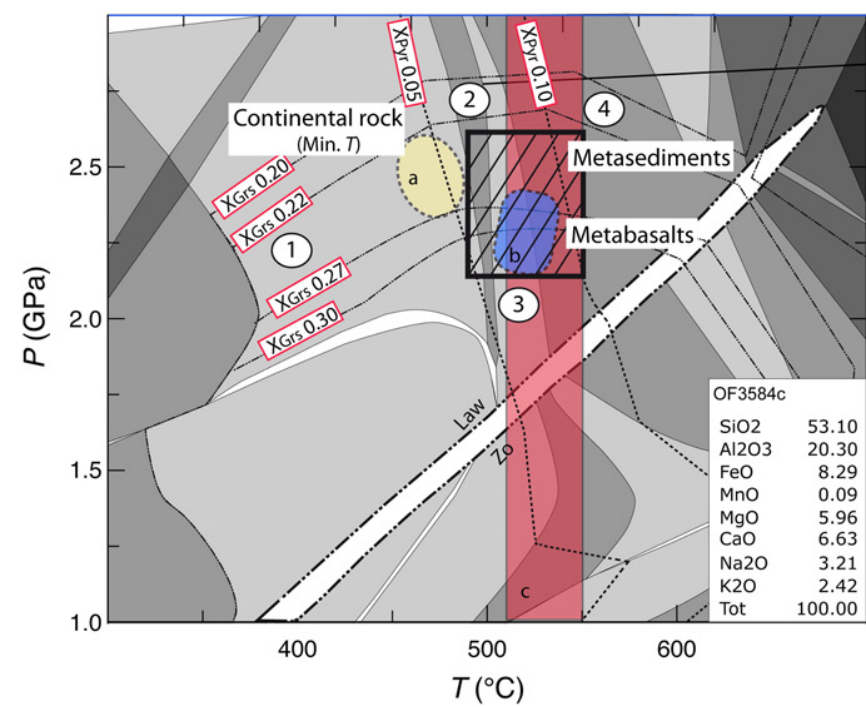

Fig. 11. $P-T$ pseudosection of continental amphibolite OF3584. Mineral assemblages are reported for fields of interest only: 1: glaucophane+phengite+garnet+lawsonite+ chlorite+omphacite+actinolite; 2: omphacite+glaucophane+actinolite+phengite + garnet+lawsonite; 3: glaucophane+phengite+garnet+lawsonite+quartz+omphacite + actin olite; and 4: glaucophane + phen gite + garnet + lawson ite + quartz + ompha-cite. White, light-, medium- and dark-gray fields are di-, tri-, quadri- and quinivariant fields, respectively. In the center of the diagram, the white elongated field indicates the lawsonite-zoisite transition: the narrow di- and tri-variant fields occurring in this part of the pseudosection, not relevant to the discussion, have not been represented in detail. Black dashed box summarizes peak P-T conditions of the MSP estimated from ophiolites, continental amphibolite and metasediments: the pale ellipsoid (a) indicates the minimum peak conditions from continental amphibolite OF3584; the dark (b) ellipsoid indicates peak-conditions from metabasalts (from Vitale Brovarone et al., 2011); and field c indicates temperatures obtained from metasediments by means of Raman Spectroscopy of Carbonaceous Materials (RSCM).

which is a reliable indicator of the peak metamorphic temperature. Because of the irreversible character of graphitization, CM structure is not sensitive to retrogression, thus recording the maximum $T$ reached during metamorphism (Beyssac et al., 2002). With this method temperature can be determined in the range $330650{ }^{\circ} \mathrm{C}$ with a precision of $\pm 50{ }^{\circ} \mathrm{C}$ due to uncertainties of petrologic data used for calibration. Relative uncertainties on $T$ are, however, much smaller (around $1015^{\circ} \mathrm{C}$ : Beyssac et al., 2004).

Raman spectra were obtained at the Institut de Minéralogie et de Physique des Milieux Condensés (IMPMC) Paris, France, using a Renishaw InVIA Reflex microspectrometer. We used a 514 nm Laser Physics argon laser in circular polarization. The laser was focused on the sample by a DMLM Leica microscope with a $100 \times$ objective $(\mathrm{NA}=0.85)$, and the laser power at the sample surface was set around $1 \mathrm{~mW}$. The Rayleigh diffusion was eliminated by edge filters, and to achieve nearly confocal configuration the entrance slit was closed down to $1015 \mu \mathrm{m}$. The signal was finally dispersed using a $1800 \mathrm{gr} /$ $\mathrm{mm}$ grating and analyzed by a Peltier cooled RENCAM CCD detector. Before each session, the spectrometer was calibrated with a silicon standard. Because Raman spectroscopy of CM can be affected by several analytical biases, we followed closely the analytical and fitting procedures described by Beyssac et al. (2002, 2003). Measurements were done on polished thin sections cut perpendicularly to the main fabrics (S0 and S1) and CM was systematically analyzed below a transparent adjacent mineral, generally quartz. 1215 spectra were recorded for each sample in the extended scanning mode (1000 2000 $\mathrm{cm}^{-1}$ ) with acquisition times from 30 to $60 \mathrm{~s}$. The spectra were then processed using the software Peakfit (Beyssac et al., 2003).

The selected samples, consisting of quartz, carbonate, white mica, and lawsonite and chloritoid pseudomorphs, yield RSCM temperatures between $510{ }^{\circ} \mathrm{C}$ and $552{ }^{\circ} \mathrm{C}$ (Table 2).
Table 2

Raman Spectroscopy of Carbonaceous Material analyses of the Monte San Petrone metasediments.

\begin{tabular}{lllllll}
\hline Sample & Locality & n. spectra & R2 & SD & $T\left({ }^{\circ} \mathrm{C}\right)$ & SE \\
\hline 0707a & Prato & 13 & 1.99 & 0.05 & 552 & 6 \\
OF3569 & Funta Favalta & 14 & 2.02 & 0.06 & 544 & 7 \\
OF3552 & M.te Muffraje & 14 & 2.83 & 0.09 & 510 & 6 \\
OF3553 & West of M.te Muffraje & 11 & 3.02 & 0.07 & 510 & 9 \\
\hline
\end{tabular}

R2 ratio with standard deviation (SD); and $T$ with standard error (SE). See Beyssac et al. (2002) for details.

\section{Comparison with similar lithological associations: new data on the Zuccarello unit}

Associated meta ophiolites, continental basement rocks and meta sedimentary cover rocks also occur in the blueschist facies Zuccarello unit (cf. Section 2.1, Fig. 1), to the south west of Bastia. The tectono stratigraphy of this area is only roughly known (Fournier et al., 1991). Meta ophiolites, such as serpentinites, ophicalcites and metabasalts occur in this area, but their relationships appear to be more complex than those described in the San Petrone unit, possibly as a result of more pervasive Alpine deformation. Despite this, similar features to the Monte San Petrone unit are locally found. In particular, the contact separating the Zuccarello continental sliver and the overlying metasedi ments is similar to the Upper Allochthon Surface of the Monte San Petrone (Figs. 4c, d and 5j). From the bottom to the top, this sequence consists of: i) Orthogneiss, whose igneous origin is suggested by the presence of variably deformed leucocratic and mafic dikes, locally only weakly transposed by Alpine deformation (Fig. 12a e). These rocks are characterized by relics of $\mathrm{K}$ feldspar wrapped around by a mica rich foliation. Glaucophane is locally observed. ii) A highly foliated phengite rich rock (Fig. 12f), similar to that described along the Upper Allochthon Surface of the Monte San Petrone (Figs. 4c and d, and $5 \mathrm{j}$ ). iii) Metaradiolarite (Fig. 12g). The characteristic purple and yellow layers, mainly consisting of piemontite and small spessartinic garnet, respectively, are typical of $\mathrm{Mn}$ rich metaradiolarite. iv) Impure marbles. v) A metaconglomerate consisting of pebbles and blocks of continental basement, quartzites, carbonates and mafic rocks in a calc micaschist matrix (Fig. 12h and i).

Ultramafic rocks occur further to the East, as both variably deformed serpentinites and ophicalcite (Fig. 12j). These ultramafic rocks are associated with by quartzite and carbonate rich metased iment. However, neither the contact between ultramafic rocks and metasediments nor their relationship with the nearby continental sliver is exposed.

\section{Discussion}

\subsection{Monte San Petrone tectono stratigraphy: a Jurassic OCT}

The Monte San Petrone lithostratigraphy is characterized by the vertical juxtaposition of serpentinites, continent derived slivers, "ophiolite type" rocks and cover metasediments. These four main lithological groups are separated by contacts that may be followed for several kilometers in a $\mathrm{N}-\mathrm{S}$ direction. The Basal Tectonic Contact (Figs. 2, 3, and 4a and e) separates the serpentinized basement from the overlying rocks (i.e. the continental sliver, "ophiolite type" rocks and metasediments). This contact has already been studied by Péquignot and Potdevin (1984), who interpreted it as an Alpine tectonic contact. However, the absence of unambiguous Alpine deformation led Péquignot and Potdevin (1984) to propose that it was established early in the Alpine evolution of the Monte San Petrone. Alternatively, we suggest that our new data indicates that the Basal Tectonic Contact and the Upper Allochthon Surface were formed prior 

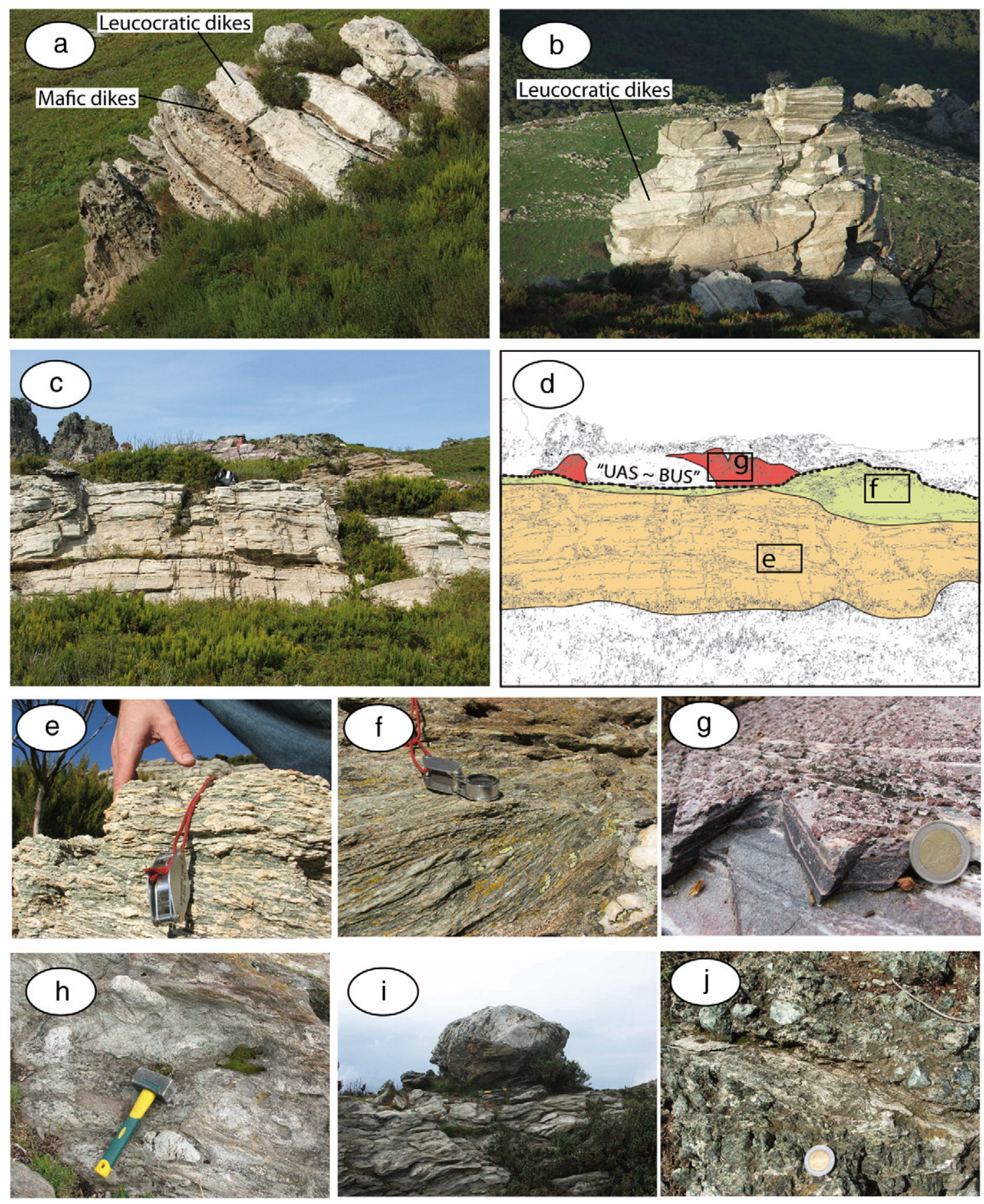

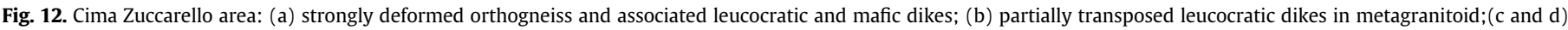

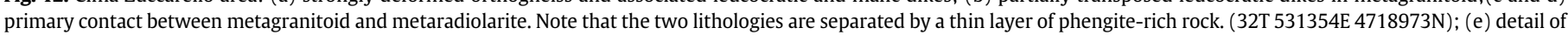

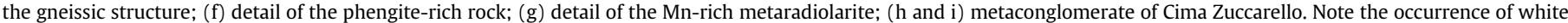
pebbles (h) and blocks (i) wrapped around by a calc-micaschist matrix; and (j) meta-ophicalcite of the Cima Zuccarello area.

to the deposition of Monte San Petrone metasediments and that they are unrelated to Alpine tectonics. There are several lines of evidence supporting this conclusion.

The Basal Tectonic Contact is locally characterized by cataclastic rocks (i.e. serpentinite breccias; Fig. 5c) that predate the formation of HP Alpine fabrics. These pre HP fault rocks, occurring at the top of the serpentinized basement, indicate that the Basal Tectonic Contact developed in the structural domain of brittle deformation. The finding of similar pre HP cataclastic structures at the bottom of the continental basement sliver suggests that the ultramafic/continental basement pair has been juxtaposed by means of a brittle tectonic contact, the Basal Tectonic Contact. Motion along this contact must have predated the juxtaposition of Mesozoic sediments, as indicated by the absence of brittle structures in the metaradiolarite overlaying the serpentinite breccias. This observation suggests that the Basal Tectonic Contact originated prior to the cover deposition.

Field data indicate that also the Upper Allochthon Surface was formed prior to or during the deposition of typical Mesozoic sediments. First of all, pebbles of continental basement rocks can be observed in the early post rift cover directly overlaying the continental basement sliver (Figs. 3, 6i, 
and 8). The presence of these clasts indicates that the Upper Allochthon Surface was already exhumed at the ocean floor prior to the deposition of the marble's protolith. Furthermore, along the Upper Allochthon surface, continental rocks and metaradiolarite are separated by a transitional contact. These two lithologies are separated marked by a phengite rich layer with a pervasive foliation ("reworked granitoid" in Figs. 4c and 8). These rocks may be interpreted as altered and/or brecciated granite, suggesting that the Upper Allochthon Surface may represent a pre Alpine tectonic surface reworked at the seafloor. In principle, two scenarios could be proposed for the origin of the Upper Allochthon Surface: i) either it is derived by complete erosion of the primary pre rift cover, predating the radiolarite deposition, ii) or it is the top of the exhumed basement that was unroofed during rifting at the footwall of large scale extensional faults. According to this latter hypothesis, pre rift sediments were never deposited above the Monte San Petrone continental basement. This hypothesis is supported both by the lack of clasts of pre rift sediments in the overlaying metasedimentary sequence, which locally contains clasts of continental basement or basalt. In both cases, the "reworked granitoid" (Figs. 4c, 5i, and 8) may correspond to the so called "tectono sedimentary breccia" that locally characterizes the continental extensional allochthons' top (Manatschal et al., 2006).

Further evidence of the pre Alpine juxtaposition of continental basement and ultramafic rocks in the Monte San Petrone area comes from the strong control exerted by the morphology of the top basement surface on the distribution and thickness of the early post rift cover, which is also an indication of the stratigraphic origin of such juxtaposition. In particular, the thicker the continental wedge, the more condensed is the early post rift cover (Fig. 3). Conversely, where the continental sliver grows thinner such as to the east of Punta Ventosa (Fig. 8b) patched silicate rich marble layers are found (Fig. $6 \mathrm{k})$. These patches might represent meta hardgrounds corresponding to condensed sequences deposited on local flats along paleoscarps filled with localized early post rift covers and continuous late post rift sediments. Thus, the variable thickness of the early post rift cover, which is covered by the homogeneous late post rift sediments, suggests that both metaradiolarite and marble precursors were deposited on a pre Alpine rugged paleotopography. This feature implies again that sediment deposition postdated the brittle deformation that led to the juxtaposition of the ultramafic/continental basement pair. The maximum age of this tectonic juxtaposition is suggested by the structural position of metaradiolarite, which overlies the lower sequence terms (i.e. serpentinites, continental rocks and "ophiolite type" rocks) by means of a stratigraphic contact (Basal Unconformity Surface and, locally, Post Rift Lower Boundary). The age of such tectonic juxtaposition is likely to be Jurassic, and more precisely the Bathonian Oxfordian, by analogy with a wealth of published studies from the peri Tethyan domain (e.g., Bill et al., 2001; Cordey and Bailly, 2007; Danelian et al., 2008). The contact between the early post rift cover and the post rift cover, the Post Rift Lower Boundary, appears to be transitional, i.e. corresponding to a primary stratigraphic contact.

In conclusion, the structural relationships among the mantle derived basement, the continental sliver and the Mesozoic sediments strongly suggest that the large scale architecture of the Monte San Petrone area corresponds to an original Jurassic Ocean Continent Transition zone. In this context, the cataclasites that mark the Basal Tectonic Contact probably represent the tectono hydrothermal type 1 ophicalcites of Tricart and Lemoine (1989), which correspond to the tectonized top of the exhumed peridotites. This surface may sample parts of a large scale low angle detachment fault, possibly responsible for the exhumation of the subcontinental mantle, by analogy with direct observations at mid ocean ridges and ophiolitic complexes (Bonatti et al., 1974; Boschi et al., 2006; Escartin et al., 2003) and in fossil OCT (Florineth and Froitzheim, 1994). In addition, pre HP cataclastic continental rocks are locally preserved in the proximity of the upper boundary of the continental sliver (Fig. 5h). Similar features are found in the Tasna fossil OCT, Eastern Alps, where the widespread brittle deformation at the top of a continental allochthon is interpreted as related to cataclastic flow along a low angle normal fault (Florineth and Froitzheim, 1994; Manatschal et al., 2006). For these reasons we interpret the Monte San Petrone brittle structures as representative of a Jurassic tectonic contact.

Also petrological and structural data, which are discussed in detail in Section 7.3.2, indicate that the different lithologies of the Monte San Petrone (i.e. ophiolites, continental rocks and metasediments) underwent a comparable Alpine $P T d$ evolution. This feature provides further support for the pre Alpine origin of the Monte San Petrone lithostratigraphy, indicating that it did not form by tectonic mixing during orogenesis, as previously proposed (Péquignot and Potdevin, 1984). Moreover, similar $P T d$ relationships between ophiolites and continental basement rocks are also described along the eastern margin of the Tenda unit (Molli et al., 2006). In that case, authors suggest that these rock types show a common tectono metamorphic evolution conditions at least from peak metamorphism. However, the possibility of an earlier association, possibly from rifting related tectonics, cannot be excluded. It seems that although strongly deformed during the Alpine tectonic history these specific rock assemblages are not really dismembered and they preserve a good record of the early inherited tectonostratigraphic architecture.

\subsection{Relationship between Tethyan architecture and Alpine deformation}

In several circumstances, the meso and macro scale geometries of the main lithological boundaries of the study area (BTC, UAS, BUS, and PRLB in Fig. 2 and following) are difficult to reconcile with the effects of Alpine deformation alone. As an example, near Monte Calleruccio, the interface between the serpentinitic basement and the overlying continental allochthon is characterized by a synformal shape (Fig. 8). Significantly, this synformal structure is discordant with respect to the nearly horizontal Alpine fabrics and is not associated with any upright fold generation, indicating that the shape of this lithological interface may be largely inherited from its pre Alpine history (Fig. 8). In addition, Alpine metamorphic fabrics are locally discordant with respect to the main MSP internal boundaries (cf. also Section 4).

Furthermore, pre Alpine geometries appear to exert a significant control on the development of Alpine structures. As an example, the large scale synformal and antiformal structures observed in the northern part of the MSP and described in Section 4 are possibly derived from Alpine superposition on a pre existing Jurassic architecture characterized by structural highs and lows.

\subsection{Tectono metamorphic evolution of the Monte san petrone OCT}

The studied unit shows a complex lithostratigraphy consisting of serpentinized peridotite, a composite middle upper continental crust, Jurassic oceanic basalts and Mesozoic sediments that was acquired during a multistage evolution, spanning from Jurassic rifting to Alpine orogenesis.

\subsubsection{Jurassic rifting}

This composite evolution may be subdivided into three main events:

1) Mantle exhumation and emplacement of the allochthonous continental slivers. The mantle continental sliver interface, which is characterized by the presence of pre Alpine brittle structures, is the only unambiguous tectonic contact of the Monte San Petrone unit. The absence of pre rift sediments and the presence of a nearly continuous layer of metaradiolarites [most likely of Callovian Oxfordian age by analogy with the dating of Bill et al. $(1997,2001)]$ on top of the basement constrain the emplacement of the continental allochthon to the Middle Upper Jurassic. 
2) The emplacement of "ophiolite type" rocks, which mainly consist of basaltic lavas and deposition of OC2 type ophicalcite, postdates the activity of the Basal Tectonic Contact. The basalt flows appear to postdate the emplacement of the continental extensional allochthon, since metabasalts rest directly on top of the serpenti nized basement and are never found between serpentinites and continental basement rocks. No clear chronological relationships between metabasalt and OC2 type ophicalcite can be inferred from field observations. We consider the deposition of OC2 type ophicalcites as syn to post continental sliver emplacement, since OC2 type ophicalcites laterally replace the continental sliver and are locally deposited on top of it.

3) The deposition of the sedimentary cover represents the last event. Early post rift cover was deposited on a rugged seafloor topogra phy, as revealed by lateral thickness variations and by the presence clasts of continental basement and basaltic rocks. Post rift cover sealed those irregular geometries with a continuous layer of sediments.

\subsubsection{Alpine orogenesis}

Petrological investigations on different high pressure rocks from the Monte San Petrone, such as continental metamafic and metasedi ments, show that all of them underwent Alpine metamorphism under comparable lawsonite eclogite facies conditions ( $T=490550{ }^{\circ} \mathrm{C}$; $P=2.22 .6 \mathrm{GPa}$ ). These data fit well with those obtained from the San Petrone metabasalts $\left(520 \pm 20^{\circ} \mathrm{C}, 2.3 \pm .01 \mathrm{GPa}\right.$ : Vitale Brovarone et al., 2011). Despite the fact that this petrological test cannot demonstrate a Jurassic origin for the Monte San Petrone lithological association, the petrological and structural data indicate that the different lithologies did not undergo independent $P T$ paths, such as systematically observed in tectonic mélanges (e.g. Agard et al., 2009; Cloos and Shreve, 1988; Federico et al., 2007; Garcia Casco et al., 2002; Shreve and Cloos, 1986). Furthermore, the Ca rich lawsonite bearing metasomatic rock marking the interface between the serpentinite and both the allochthonous continental sliver and the

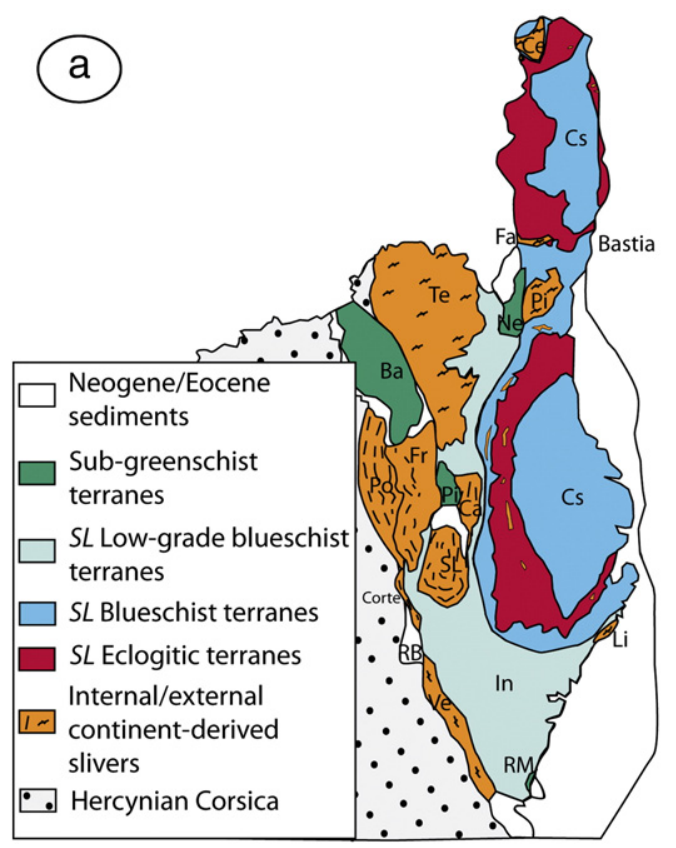

metasedimentary cover, confirms that those lithologies were already associated at peak metamorphic conditions.

The Alpine HP tectono metamorphic evolution is documented by the well preserved eclogitic assemblages associated with progressive deformation, which is responsible for the development of ten meter scale sheath folds in the continental wedge or hundred meter scale isoclinal folds in the calcschists. The mean dip direction of the HP foliations (N270) is consistent all over the studied area, minor variations being associated to later Alpine structures. The retrograde evolution shows lawsonite breakdown under epidote blueschist facies followed by a mostly static greenschist facies overprint.

\subsection{Other occurrences of OCT related lithostratigraphic associations in alpine Corsica}

As mentioned above, most of the tectono metamorphic units of the Schistes Lustrés are characterized by the association of ophiolites, especially serpentinites, and scattered continental slivers (Fig. 1). The regional distribution of the continental slivers described in the literature and their metamorphic conditions is reported in Fig. 13. These continental slivers are found all over the Schistes Lustrés domain, with the exception of the metasedimentary Castagniccia unit and most of the Inzecca domain, and show different tectono metamorphic evolution with peaks up to lawsonite eclogite facies conditions (Fig. 13a).

In the Campitello, Pigno and Farinole units (Lahondère, 1996) the tectono stratigraphy and architecture are very similar to the Monte San Petrone unit (cf. Section 2.1). In particular, in the Campitello and Farinole units, which underwent blueschist and eclogite facies conditions, respectively, serpentinites, continental slivers and Meso zoic cover rocks are juxtaposed (Lahondère, 1996). Furthermore, in the Campitello unit a pre rift Triassic carbonate cover was directly deposited, or juxtaposed, on top of the continental sliver (Rossi et al., 2003). This feature is recurrent at both present day (e.g., Hobby High: Whitmarsh et al., 1998) and fossil OCTs (e.g., Err Platta nappe: Froitzheim and Eberli, 1990; Manatschal and Nievergelt, 1997), where continental allochthons may consist of upper crust basement with its

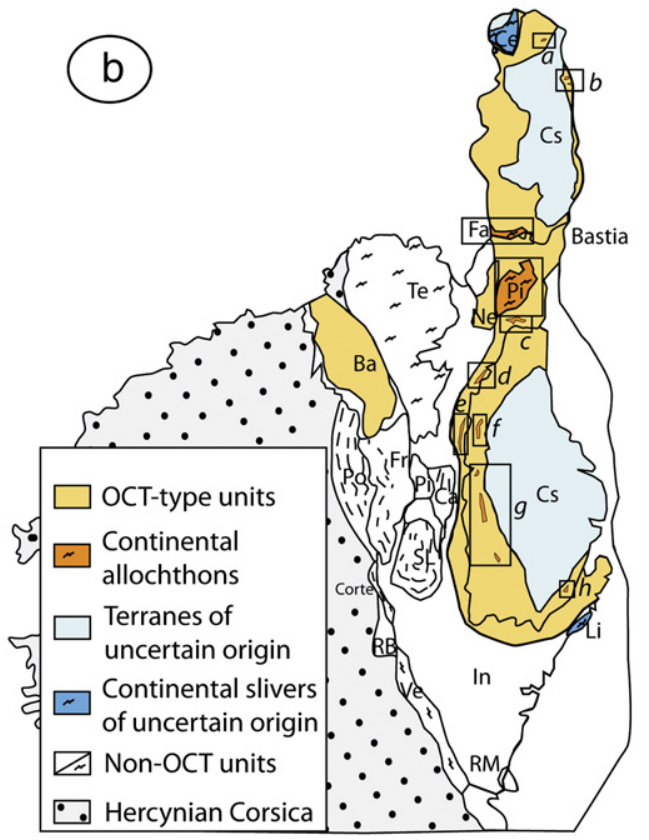

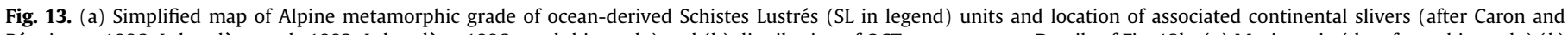

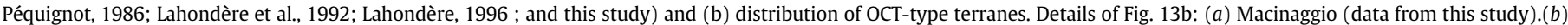

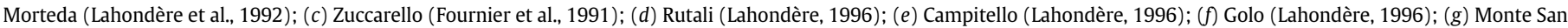

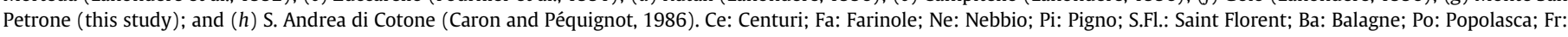
Francardo; Ca: Caporalino; SL: Santa Lucia; Ve: Vecchio; Li: Linguizetta; Te: Tenda massif; In: Inzecca region; RM: Rio Magno; Pi: Pineto; and Ma: Macinaggio. 
pre rift sedimentary cover. Despite detailed lithostratigraphic studies on these areas are still lacking, the main geological features point to inherited OCTs, as already suggested by Lahondère (1996). In the Serra di Pigno area, primary stratigraphic contacts separating continental basement rocks and serpentinites by the overlying metasediments are observed (Meresse, 2006).

In the Monte Zuccarello area, despite the lithological associations being similar to that of the Monte San Petrone, clear tectono stratigraphies are only locally observed. In particular, continental basement rocks and $\mathrm{Mn}$ rich metaradiolarites are separated by a transitional contact characterized by the occurrence of a phengite rich rock similar to the "reworked granitoid" of Monte San Petrone unit. This sequence suggests a primary transition from a continental allochthon sliver to its Jurassic sedimentary cover (i.e., radiolarite). As further evidence, the overlying metaconglomerate contains clasts of the underlying rocks, suggesting their primary relationships. Like the Monte San Petrone unit, these data suggest that the Zuccarello unit corresponds to an OCT lithological association.

For the Balagne Nebbio Nappe the original proximal position with respect to a continental source may be postulated exclusively on the basis of the presence of continent derived debris, interbedded at different horizons all along the stratigraphic succession, starting from the Jurassic basalts (Durand Delga et al., 1997) up to the upper Cretaceous sequences (Marroni and Pandolfi, 2003; Sagri et al., 1982). In addition, in the Nebbio Nappe, an OCT pertinence is supported by the E MORB Jurassic basalt affinity (Saccani et al., 2000). These features are possibly consistent with an OCT paleogeographic origin for the Balagne Nappe.

On the basis of the data presented above, it is apparent that tectonometamorphic units derived from Jurassic OCTs may be sampled during orogenesis. In the case of Alpine Corsica, such slices extend for tens of kilometers in the N S direction (Fig. 13b) and show consistent peak metamorphic conditions under blueschist or eclogite facies conditions. Such elongated domains, which exhibit consistent lithos tratigraphic associations and tectonometamorphic evolution, may represent coherent portions of the Tethyan basin that, based on their paleogeographic position, underwent a different Alpine evolution.

The abundance of transitional domains with respect to more distal oceanic units in Alpine Corsica conveys the relevance of OCTs in the Tethys Alps system. This observation may indicate that the Piemonte Liguria basin (i.e. the western part of the Tethys ocean) might have mostly consisted of OCTs separating the European and African plates, as already suggested by the pioneering study of Decandia and Elter (1972) in the Apennines and later by Manatschal and Müntener (2009) in the Alps. Alternatively, the relative abundance of OCT derived units may indicate that OCT's are more easily exhumed than typical oceanic domains. This may be due both to the presence of continental slivers and to the abundance of serpentinites, which may foster their exhumation processes with respect to the denser internal zones.

\section{Conclusions}

The tectono stratigraphy and large scale architecture of the eclogite facies Monte San Petrone unit are very similar to those observed at modern Ocean Continent Transition zones. In particular, the study area preserves primary pre Alpine contacts among serpentinized peridotites, continental basement rocks and oceanic metasedimentary cover. Such relationships are locally recognizable despite the pervasive Alpine tectono metamorphic overprint, including diffuse shearing at lawsonite eclogite facies conditions.

Petrology confirms that different lithologies of the Monte San Petrone tectono stratigraphy, such as the continental allochthonous rocks, meta ophiolite and oceanic metasediments underwent com parable peak metamorphic conditions in the lawsonite eclogite facies field at $T=490550{ }^{\circ} \mathrm{C}$ and $P=2.22 .6 \mathrm{GPa}$. This feature, together with the fact that retrograde overprint is limited, suggests that the whole units underwent the same Alpine tectono metamorphic evolution.

Comparable OCT type lithological associations occur in most of the Alpine Corsica and show different Alpine metamorphic evolutions. These terranes form N S elongated tectono metamorphic domains that can be followed for several tens of kilometers along strike.

The study of OCT type terranes in high pressure belts may provide unique access to the most distal parts of rifted margins, as opposed to the seemingly more proximal exhumed mantle domains preserved in less metamorphosed orogens, such as the Eastern Alps.

\section{Acknowledgments}

A.V. B. is grateful to F. Dela Pierre, G. Molli, and C. Bertok for their discussions and suggestions. Part of this research has been funded by the Vinci 2008 and Galileo 2009 grants, UIF UFI. G. Manatschal, N. Froitzheim, and F. Rossetti, the editors and an anonymous reviewer are thanked for the very useful comments and suggestions that improved the original manuscript.

\section{References}

Agard, P., Yamato, P., Jolivet, L., Burov, E., 2009. Exhumation of oceanic blueschists and eclogites in subduction zones: timing and mechanisms. Earth Science Reviews 92, 53

Alsop, G.I., Holdsworth, R.E., 2004. The geometry and topology of natural sheath folds: a new tool for structural analysis. Journal of Structural Geology 26, 1561-1589. Ballèvre, M. Merle, O., 1993. The Combin fault: compressional reactivation of a Late Cretaceous-Early Tertiary detachment fault in the Western Alps. Schweizerische Mineralogische und Petrographische Mitteilungen 73, 205-227.

Beccaluva, L., Ohnenstetter, D., Ohnenstetter, M., Venturelli, G., 1977. The trace element geochemistry of Corsican ophiolites. Contribution to Mineralogy and Petrology 64, 11 31

Beltrando, M., Rubatto, D., Manatschal, G., 2010. From passive margins to orogens: the link between Ocean-Continent transition zones and (ultra) high pressure metamorphism. Geology 38, 559-562.

Beyssac, O., Goffé, B., Chopin, C., Rouzaud, J.N., 2002. Raman spectra of carbonaceous material in metasediments: a new geothermometer. Journal of Metamorphic Geology 20, 859-871.

Beyssac, O., Goffé, B., Petitet, J.P., Froigneux, E., Moreau, M., Rouzaud, J.N., 2003. On the characterization of disordered and heterogeneous carbonaceous materials using Raman spectroscopy. Spectrochimica Acta A 59, 2267-2276.

Beyssac, O., Bollinger, L., Avouac, J.P., Goffé, B., 2004. Thermal metamorphism in the lesser Himalaya of Nepal determined from Raman spectroscopy of carbonaceous material. Earth and Planetary Science Letters 225, 233-241.

Bezert, P., Caby, R., 1988. Sur l'âge post-bathonien des événements tectonométamorphiques alpines en bordure orientale de la Corse cristalline. Bulletin de

la Societe Geologique de France 8, 965-971.

Bill, M., Bussy, F., Cosca, M., Masson, H., Hunziker, J.C., 1997. High-precision U-Pb and Ar-40/Ar-39 dating of an Alpine ophiolite (Gets nappe, French Alps). Eclogae Geologicae Helvetiae 90, 43-54.

Bill, M. O'Dogherty, L, Guex, J., Baumgartner, P.O., Masson, H., 2001. Radiolarite ages in Alpine-Mediterranean ophiolites: constraints on the oceanic spreading and the Tethys-Atlantic connection. Geological Society of America Bulletin 113, 129-143.

Boillot, G., Grimaud, S., Mauffret, A., Mougenot, D., Kornprobst, J., Mergoil-Daniel, J. Torrent, G., 1980. Ocean-Continent boundary off the Iberian margin: a serpentinite diapir west of the Galicia Bank. Earth and Planetary Science Letters 48, 23-34.

Boillot, G., et al., 1987. Tectonic denudation of the upper mantle along passive margins: a model based on drilling results (ODP Leg 103, western Galicia margin, Spain). Tectonophysics 132, 335-342.

Bonatti, E., Emiliani, C., Ferrara, G., Honnorez, J., Rydell, H., 1974. Ultramafic carbonate breccias from equatorial mid-Atlantic ridge. Marine Geology 16, 83-102.

Boschi, C., Früh-Green, G.L., Delacour, A., Karson, J.A., Kelley, D.S., 2006. Mass transfer and fluid flow during detachment faulting and development of an oceanic core complex, Atlantis Massif (MAR $30^{\circ} \mathrm{N}$ ). Geochemistry, Geophysics, Geosystems 7, Q01004. doi:10.1029/2005GC001074.

Bousquet, R., 2008. Metamorphic heterogeneities within a same HP unit: overprint effect or metamorphic mix? Lithos 103, 46-69.

Brouwer, F.M., Burri, T., Engi, M., Berger, A., 2005. Eclogite relics in the Central Alps:

PT- evolution, Lu-Hf ages, and implications for formation of tectonic mélange zones. Schweizerische Mineralogische und Petrographische Mitteilungen 85, 147-174 (Central Alps Special Issue, published in 2007).

Brunet, C., Monié, P., Jolivet, L., Cadet, J.P., 2000. Migration of compression and extension in the Tyrrhenian Sea, insights from $40 \mathrm{Ar} / 39 \mathrm{Ar}$ ages on micas along a transect from Corsica to Tuscany. Tectonophysics 321, 127-155.

Caron, J.M., 1994. Metamorphism and deformation in Alpine Corsica. Schweizerische Mineralogische und Petrographische Mitteilungen 7, 105-114.

Caron, J.M., Delcey, R., 1979. Lithostratigraphie des schistes lustrés corses: diversité des séries post-ophiolitiques. Comptes Rendus Académie des Sciences 208, 1525-1528 Paris. 
Caron, J.M., Péquignot, G., 1986. The transition between blueschist and lawsonite bearing eclogites. Example of Corsican metabasalt. Lithos 19, 205-218.

Caron, J.-M., Kiénast, J.-R., Triboulet, C., 1981. High-pressure/low temperature metamorphism and polyphase Alpine deformation at Sant'Andrea di Cotone (eastern Corsica, France). Tectonophysics 78, 419-451.

Caron, J.M., Loÿe-Pilot, M.D., Conchon, O., Scius, H., 1990. Carte géol. France (1/50000), feuille Pietra di Verde (1115). BRGM, Orléans. 51 pp.

Castelli, D., Rolfo, F., Groppo, C., Compagnoni, R., 2007. Impure marbles from the UHP Brossasco-Isasca Unit (Dora-Maira Massif, western Alps): evidence for Alpine equilibration in the diamond stability field and evaluation of the $\mathrm{X}\left(\mathrm{CO}_{2}\right)$ fluid evolution. Journal of Metamorphic Geology 25, 587-603.

Clarke, G.L., Powell, R., Fitzherbert, J.A., 2006. The lawsonite paradox: a comparison ofvfield evidence and mineral equilibrium modeling. Journal of Metamorphic Geology 24, 715-725.

Cloos, M., Shreve, R.L., 1988. Subduction-channel model of prism accretion, melange formation, sediment subduction, and subduction erosion at convergent plate margins: 2. Implications and discussion. Pure and Applied Geophysics 128, 501-545.

Coleman, R.G., 1977. Ophiolites. Springer, Berlin.

Connolly, J.A.D., 1990. Multivariable phase diagrams: an algorithm based on generalized thermodynamics. American Journal of Science 290, 666-718

Cordey, F., Bailly, A., 2007. Alpine ocean seafloor spreading and onset of pelagic sedimentation: new radiolarian data from the Chenaillet-Montgenèvre ophiolite (French-Italian Alps). Geodinamica Acta 20, 131-138.

Dal Piaz, G.V., 1999. The Austroalpine-Piedmont nappe stack and the puzzle of Alpine Tethys. Memorie di Scienze Geologiche (Padova) 51, 155-176.

Dal Piaz, G.V., Zirpoli, G., 1979. Occurrence of eclogite relics in the ophiolite nappe from Marine d'Albo, Northern Corsica. Neues Jahrbuch für Mineralogie 3, 118-122.

Danelian, T., De Wever, P., Durand-Delga, M., 2008. Revised radiolarian ages for the sedimentary cover of the Balagne ophiolite (Corsica, France). Implications for the palaeoenvironmental evolution of the Balano-Ligurian margin. Bulletin de la Societe Geologique de France 179, 289-296.

Decandia, F.A., Elter, P., 1972. La zona ofiolitifera del Bracco nel settore compreso tra Levanto e la Val Graveglia (Appennino Ligure). Memorie della Società Geologica Italiana 11, 503-530.

Desmurs, L., Müntener, O., Manatschal, G., 2002. Onset of magmatic accretion within a magma-poor passive margin: a case study from the Err-Platta Ocean-Continent transition, Eastern Switzerland. Contributions to Mineralogy and Petrology 144, 365-382.

Durand-Delga, M., 1978. Corse. Guides géologiques régionaux, Masson, Paris. 208 pp.

Durand-Delga, M., 1984. Principaux traits de la Corse Alpine et corrélations avec les Alpes Ligures. Memorie della Società Geologica Italiana 28, 285-329.

Durand-Delga, M., Peybernés, B., Rossi, P., 1997. Arguments en faveur de la position, au Jurassique, des ophiolites de Balagne (Haute-Corse, France) au voisinage de la marge continentale européenne. Comptes Rendus Académie des Sciences, Paris 325, 973-981.

Escartin, J., Mevel, C., MacLeod, C.J., McCaig, A.M., 2003. Constraints on deformation conditions and the origin of oceanic detachments: the Mid-Atlantic ridge core complex at $15^{\circ} 45^{\prime} \mathrm{N}$. Geochemistry, Geophysics, Geosystems 4. doi:10.1029/ 2002GC000472.

Evans, T.P., 2004. A method for calculating effective bulk composition modification due to crystal fractionation in garnet-bearing schist: implication for isopleth thermobarometry. Journal of Metamorphic Geology 22, 547-557.

Faure, M., Malavieille, J., 1981. Étude structurale d'un cisaillement ductile: le charriage ophiolitique Corse dans la région de Bastia. Bulletin de la Societe Geologique de France 23, 335-343.

Federico, L., Crispini, L., Scambelluri, M., Capponi, G., 2007. Ophiolite mélange zone records exhumation in a fossil subduction channel. Geology 35, 499-502.

Ferraris, C., Castelli, D., Lombardo, B., 2005. SEM/TEM-AEM characterization of micro- and nano-scale zonation in phengite from a UHP Dora-Maira marble: petrologic significance of armoured Si-rich domains. European Journal of Mineralogy 17, 453-464.

Florineth, D., Froitzheim, N., 1994. Transition from continental to oceanic basement in the Tasna nappe (Engadine window, Graubünden, Switzerland): evidence for Early Cretaceous opening of the Valais ocean. Schweizerische Mineralogische und Petrographische Mitteilungen 74, 437-448

Folk, R.L., McBride, E.F., 1976. Possible pedogenic origin of Ligurian ophicalcite: a Mesozoic calichified serpentinite. Geology 4, 327-332.

Forster, M.A., Lister, G.S., Compagnoni, R., Giles, D., Hills, Q., Betts, P.G., Beltrando, M. Tamagno, E., 2004. Mapping of oceanic crust with "HP" to "UHP" metamorphism: the Lago di Cignana Unit (Western Alps). In: Pasquarè, G., Venturini, C., Groppelli, G. (Eds.), Mapping Geology in Italy, APAT-Dipartimento Difesa del Suolo-Servizio Geologico d'Italia, Roma 2004 (2006), Map 33, 279-286. S.EL.CA, Firenze.

Fournier, M., Jolivet, L., Goffé, B., Dubais, R., 1991. The Alpine Corsica metamorphic core complex. Tectonics 10, 1173-1186.

Froitzheim, N., Eberli, G.P., 1990. Extensional detachment faulting in the evolution of a Tethys passive continental margin, eastern Alps, Switzerland. Geological Society of America Bulletin 102, 1297-1308.

Froitzheim, N., Manatschal, G., 1996. Kinematics of Jurassic rifting, mantle exhumation, and passive-margin formation in the Austroalpine and Penninic nappes (eastern Switzerland). Geological Society of America Bulletin 10, 1120-1133.

Gaidies, F., Abart, R., De Capitani, C., Schuster, R., Connolly, J.A.D., Reusser, E., 2006 Characterization of polymetamorphism in the Austroalpine basement east of the Tauern Window using garnet isopleth thermobarometry. Journal of Metamorphic Geology 24, 451-475.

Garcia-Casco, A., Torres-Roldan, R.L., Millan, G., Monié, P., Schneider, J., 2002. Oscillatory zoning in eclogitic garnet and amphibole, Northern Serpentinite Melange, Cuba: record of tectonic instability during subduction? Journal of Metamorphic Geology 20, 581-598.
Garfagnoli, F., Menna, F., Pandeli, E., Principi, G., 2009. Alpine metamorphic and tectonic evolution of the Inzecca-Ghisoni area (southern Alpine Corsica, France). Geological Journal 44, 191-210.

Gerya, T.V., Stöckhert, B., Perchuk, A.L., 2002. Exhumation of high pressure metamorphic rocks in a subduction channel-a numerical simulation. Tectonics $21(6-1), 6-19$

Ghent, E.D., Tinkham, D., Marr, R., 2009. Lawsonite eclogites from the Pinchi Lake area, British Columbia - new P-T estimates and interpretation. Lithos 109, 248-253.

Hermann, F., 1937. Carta Geologica delle Alpi nord-occidentali alla scala 1:200,000. Fogli W e E. Arti Grafiche Moreschi e \& C., Milano. Ufficio Cartografico S.A.C.A.R.T.A, Milano.

Hermann, J., Müntener, O., 1996. Exhumation-related structures in the Malenco-Margna system: implications for paleogeography and its consequences for rifting and Alpine tectonics. Schweizerische Mineralogische und Petrographische Mitteilungen 81, 239-255.

Holland, T.J.B., Powell, R., 1996. Thermodynamics of order-disorder in minerals, 2. Symmetric formalism applied to solid solutions. American Mineralogist 81, 1425-1437.

Holland, T.J.B., Powell, R., 1998. An internally consistent thermodynamic data set for phases of petrologic interest. Journal of Metamorphic Geology 16, 309-343.

Jackson, M.D., Ohnenstetter, M., 1981. Peridotite and gabbroic structures in the Monte Maggiore massif, Alpine Corsica. Journal of Geology 89, 703-719.

Jolivet, L., Dubois, R., Fournier, M., Goffé, B., Michard, A., Jourdan, C., 1990. Ductile extension in Alpine Corsica. Geology 18, 1007-1010.

Lahondère, D., 1996. Les schistes blues et les éclogites à lawsonite des unités continentales et océanique de la Corse alpine. Nouvelles donnée pétrologique et structurales (Corse). Documents du BRGM. 240 pp.

Lahondère, D., Guerrot, C., 1997. Datation Nd-Sm du métamorphisme éclogitique en Corse alpine: un argument pour l'existence, au Crétacé supérieur, d'une zone de subduction active localisée le long du block corse-sarde. Géologie de la France 3, 3-11.

Lahondère, J.C., Lahondère, D., Lluch, D., Ohnenstetter, M., Dominici, R., Vautralle, C., 1992. Carte géologique de la France a 1/50000. Luri, BRGM

Leake, B.E., Wooley, A.R., et al., 1997. Nomenclature of amphiboles: report of the subcommittee on amphiboles of the International Mineralogical Association, commission on new minerals and mineral names. Canadian Mineralogist 35, 219-246.

Malasoma, A. Marroni, M. Musumeci, G. Pandolfi, L, 2006. High-pressure mineral assemblage in granitic rocks from continental units in Alpine Corsica, France. Geological Journal 41, 49-59.

Malavieille, J., 1983. Étude tectonique et microtectonique de la nappe de socle de Centuri (zone des Schistes Lustrés de Corse). Conséquences pour la géométrie de la chaîne alpine. Bulletin de la Societe Geologique de France 25, 195-204.

Manatschal, G., 2004. New models for evolution of magma-poor rifted margins based on a review of data and concepts from West Iberia and the Alps. International Journal of Earth Sciences 93, 432-466.

Manatschal, G., Engström, A., Desmurs, L., Schaltegger, U., Cosca, M., Müntener, O., Bernoulli, D., 2006. What is the tectono-metamorphic evolution of continental break-up: the example of the Tasna Ocean-Continent transition. Journal of Structural Geology 28, 1849-1869.

Manatschal, G., Müntener, O., 2009. A type sequence across an ancient magma-poor Ocean-Continent transition: the example of the western Alpine Tethys ophiolites. Tectonophysics 473, 4-19.

Manatschal, G., Nievergelt, P., 1997. A continent-ocean transition recorded in the Err and Platta nappes (Eastern Switzerland). Eclogae Geologicae Helvetiae 90, 3-27.

Marroni, M., Pandolfi, L., 2003. Deformation history of the ophiolite sequence from the Balagne Nappe, northern Corsica: insights in the tectonic evolution of Alpine Corsica. Geological Journal 38, 67-83.

Marroni, M., Molli, G., Montanini, A., Tribuzio, R., 1998. The association of continental crust rocks with ophiolites in the Northern Apennines (Italy): implications for continent-ocean transition in the Western Tethys. Tectonophysics 292, 43-66.

Marroni, M., Molli, G., Montanini, A., Ottria, G., Pandolfi, L., Tribuzio, R., 2002. The External Liguride units (Northern Apennine, Italy) from rifting to convergence of a fossil Ocean-Continent transition zone. Ofioliti 27, 119-131.

Marroni, M., Pandolfi, L., Ribecai, C., 2004. Palynological dating of the Alturaia Arkose (Balagne, northern Corsica): geological implications. Comptes Rendus Paleovol 3, 643-651. doi:10.1016/j.crpv.2004.07.014.

Martin, L., Rubatto, D., Vitale Brovarone, A., Hermann, J., (under review). Late Eocene lawsonite-eclogite facies metasomatism of a granulite sliver associated to ophiolites in Alpine Corsica. Lithos.

Mattauer, M., Faure, M., Malavieille, J., 1981. Transverse lineation and large-scale structures related to Alpine obduction in Corsica. Journal of Structural Geology 3, 401-409.

Meresse, F., 2006. La transition Ocean-Continent (TOC) de la marge alpine jurassique reconstituée dans les unités océaniques de haute pression du Cap Corse. Master Thesis, Univ. Montpellier II, France.

Molli, G., 2008. Northern Apennine-Corsica orogenic system: an updated overview. In: Siegesmund, S., Fügenschuh, B., Froitzheim, N. (Eds.), Tectonic Aspects of the Alpine-Dinaride-Carpathian System. : Geological Society, 298. Special Publications, London, pp. 413-442.

Molli, G., Tribuzio, R., Marquer, D., 2006. Deformation and metamorphism at the eastern border of the Tenda Massif (NE Corsica): a record of subduction and exhumation of continental crust. Journal of Structural Geology 29, 1748-1766.

Newton, R.C., Charlu, T.V., Kleppa, O.J., 1980. Thermochemistry of the high structural state plagioclases. Geochimica et Cosmochimica Acta 44, 933-941.

Padoa, E., Saccani, E., Durand-Delga, M., 2001. Structural and geochemical data on the Rio Magno Unit: evidence of a new 'Apenninic' ophiolitic unit in Alpine Corsica and its geodynamic implications. Terra Nova 13, 135-142. 
Péquignot, G., Potdevin, J.L., 1984. Métamorphisme et tectonique dans les Schistes Lustrés à l'Est de Corte (Corse). Univ. Claude-Bernard (Lyon), Thèse $3^{\text {me }}$ cycle, 3 voll., $245 \mathrm{pp}$

Péron-Pinvidic, G., Manatschal, G., 2009. The final rifting evolution at deep magma-poor passive margins from Iberia-Newfoundland: a new point of view. International Journal of Earth Sciences 98, 1581-1597.

Piccardo, G.B., Guarnieri, L., 2010. The Monte Maggiore peridotite (Corsica, France): a case study of mantle evolution in the Ligurian Tethys. The Geological Society of London, Special Publications 337, 7-45.

Pouchou, J.L., Pichoir, F., 1988. Determination of mass absorption coefficients for soft XRays by use of the electron microprobe. In: Newbury, D.E. (Ed.), Microbeam Analysis. San Francisco Press, pp. 319-324.

Rampone, E., Hofmann, A.W., Raczek, I., 2009. Isotopic equilibrium between mantle peridotite and melt: evidence from the Corsica ophiolite. Earth and Planetary Science Letters 288, 601-610.

Reddy, S.M., Wheeler, J., Butler, R.H.W., Cliff, R.A., Freeman, S., Inger, S., Pickles, C., Kelley, S.P., 2003. Kinematic reworking and exhumation within the convergent Alpine Orogen. Tectonophysics 365, 77-102.

Rossi, Ph., Durand-Delga, M., Lahondère, J. C. and Coll. (Baud J. P., Égal E., Lahondère D. Laporte D., Lluch D., Loÿle M. D., Ohnenstetter M., Palagi P.), 2003. Carte géol. France (1/50000), feuille Santo Pietro di Tenda (1106). Orléans: BRGM. Notice explicative par Rossi, Ph., Durand-Delga, M., Lahondère, J.C., Lahondère, D., 224 pp.

Saccani, E., Padoa, E., Tassinari, R., 2000. Preliminary data on the Pineto gabbroic massif and Nebbio basalts: progress toward the geochemical characterization of Alpine Corsica ophiolites. Ofioliti 25, 75-85.

Sagri, M., Aiello, E., Certini, L., 1982. Le unità torbiditiche cretacee della Corsica. Rendiconti della Società Geologica d'Italia 5, 87-91.

Sauvage-Rosemberg, M., 1977. Tectonique et microtectonique des schistes lustrés et ophiolites del la vallée du Golo (Corse Alpine). Thèse $3^{\text {ème }}$ cycle. Univ. Montpellier, 83p.
Sedan, O., 1983. Étude cartographique et structurale d'un secteur de la Corse Alpine. La zone de la nappe des schistes lustrés (canton de Morosaglia). Thèse $3^{\text {ème }}$ cycle, Univ. Marseille, 105p.

Shreve, R.L., Cloos, M., 1986. Dynamics of sediment subduction, melange formation, and prism accretion. Journal of Geophysical Research 91 (B10), 10229-10245.

Tribuzio, R., Giacomini, F., 2002. Blueschist facies metamorphism of peralkaline rhyolites from the Tenda crystalline massif (northern Corsica): evidence for involvement in the Alpine subduction event? Journal of Metamorphic Geology 20 (5), 513-526.

Tricart, P.E., Lemoine, M., 1989. The Queyras ophiolite west of Monte Viso (Western Alps): indicator of a peculiar ocean floor in the Mesozoic Tethys. Journal of Geodynamics 13, 163-181.

Venturelli, G., Thorpe, R.S., Potts, P.J., 1981. Rare earth and trace element characteristics of ophiolitic metabasalts from the Alpine-Apennine belt. Earth and Planetary Science Letters 53, 109-123.

Vitale Brovarone, A., Groppo, C., Hetenyi, G., Compagnoni, R., Malavieille, J., 2011. Coexistence of lawsonite-eclogite and blueschist: phase diagram calculations from Alpine Corsica metabasalts. Journal of Metamorphic Geology. doi:10.1111/ j.1525-1314.2011.00931.x.

Wei, C.J., Powell, R., 2003. Phase relations in high-pressure metapelites in the system KFMASH $\left(\mathrm{K}_{2} \mathrm{O}-\mathrm{FeO}-\mathrm{MgO}-\mathrm{Al}_{2} \mathrm{O}_{3}-\mathrm{SiO}_{2}-\mathrm{H}_{2} \mathrm{O}\right)$ with application to natural rocks Contributions to Mineralogy and Petrology 145, 301-315.

White, R.W., Powell, R., Phillips, G.N., 2003. A mineral equilibria study of the hydrothermal alteration in mafic greenschist facies rocks at Kalgoorlie, Western Australia. Journal of Metamorphic Geology 21, 455-468.

Whitmarsh, R.B., Beslier, M.O., Wallaa, P., 1998. Proceedings of the Ocean Drilling Program, Initial Reports 173 (CD-ROM), Ocean Drilling Program, College Station, TX 